\title{
A contribution to the selection of tsunami human vulnerability indicators: conclusions from tsunami impacts in Sri Lanka and Thailand (2004), Samoa (2009), Chile (2010) and Japan (2011)
}

\author{
P. González-Riancho ${ }^{1}$, B. Aliaga ${ }^{2}$, S. Hettiarachchi ${ }^{3}$, M. González ${ }^{1}$, and R. Medina ${ }^{1}$ \\ ${ }^{1}$ Environmental Hydraulics Institute "IH Cantabria", Universidad de Cantabria, C/Isabel Torres no 15, \\ Parque Científico y Tecnológico de Cantabria, 39011 Santander, Spain \\ ${ }^{2}$ Intergovernmental Oceanographic Commission of UNESCO, 7 Place de Fontenoy, 75732 Paris CEDEX 07, France \\ ${ }^{3}$ Department of Civil Engineering, University of Moratuwa, 10 Simon Abeywickrama Avenue, \\ Mount Lavinia, 10370, Sri Lanka
}

Correspondence to: P. González-Riancho (grianchop@unican.es)

Received: 11 September 2014 - Published in Nat. Hazards Earth Syst. Sci. Discuss.: 16 December 2014

Revised: 01 June 2015 - Accepted: 03 June 2015 - Published: 03 July 2015

\begin{abstract}
After several tsunami events with disastrous consequences around the world, coastal countries have realized the need to be prepared to minimize human mortality and damage to coastal infrastructures, livelihoods and resources. The international scientific community is striving to develop and validate methodologies for tsunami hazard and vulnerability and risk assessments. The vulnerability of coastal communities is usually assessed through the definition of sets of indicators based on previous literature and/or post-tsunami reports, as well as on the available data for the study site. The aim of this work is to validate, in light of past tsunami events, the indicators currently proposed by the scientific community to measure human vulnerability, to improve their definition and selection as well as to analyse their validity for different country development profiles. The events analysed are the 2011 Great Tohoku tsunami, the 2010 Chilean tsunami, the 2009 Samoan tsunami and the 2004 Indian Ocean tsunami. The results obtained highlight the need for considering both permanent and temporal human exposure, the former requiring some hazard numerical modelling, while the latter is related to site-specific livelihoods, cultural traditions and gender roles. The most vulnerable age groups are the elderly and children, the former having much higher mortality rates. Female mortality is not always higher than male mortality and not always related to dependency issues. Higher numbers of disabled people do not always translate into higher numbers of victims. Besides, it is clear that mortality is not only related to the characteristics of the population but also of the buildings. A high correlation has been found between the af-
\end{abstract}

fected buildings and the number of victims, being very high for completely damaged buildings. Distance to the sea, building materials and expected water depths are important determining factors regarding the type of damage to buildings.

\section{Introduction}

Natural disasters are triggered by extreme natural phenomena and become disasters because of the heightened vulnerability of the people and places where they occur (Mazurana et al., 2011). Vulnerability refers to the conditions determined by physical, social, economic and environmental factors or processes, which increase the susceptibility of the exposed elements to the impact of hazards (adapted from UN/ISDR, 2004).

Earthquakes (including tsunamis) have killed more people than all other types of disaster put together, claiming nearly 750000 lives between 1994 and 2013. Tsunamis were the most deadly sub-type of earthquake, with an average of 79 deaths for every 1000 people affected, compared to four deaths per 1000 for ground movements. This makes tsunamis almost 20 times more deadly than ground movements (CRED, 2015).

With the aim of reducing the negative consequences of a potential tsunami event in a certain area, the scientific community is developing methodologies to better understand the tsunami hazard itself (Goseberg and Schlurmann, 2009; Harbitz et al., 2012; Álvarez-Gómez, 2013; Greiving et al., 2006, 
etc.) and the vulnerability conditions that may exacerbate the tsunami impacts (UNDP, 2011; UNU-EHS, 2009; Villagrán de León, 2008; González-Riancho et al., 2014; Sugimoto et al., 2003; Sato et al., 2003; Koshimura et al., 2006; Jonkman et al., 2008; Strunz et al., 2011; Post et al., 2009; Dwyer et al., 2004; Tinti et al., 2011; Dall'Osso et al., 2009; Cruz et al., 2011; Grezio et al., 2012; Koeri, 2009; Eckert et al., 2012; etc.).

As vulnerability is multi-dimensional, scale dependent and dynamic (Vogel and O'Brien, 2004), according to the scope of their work, various authors focus either on a specific dimension (i.e. human, ecological, socioeconomic, infrastructural) or on an integrated approach when dealing with coupled human and natural systems. Most of the vulnerability assessments are carried out by means of the definition of a set of indices and indicators which are normalized, weighted, aggregated and classified through a variety of methods to geographically represent the information (OECD, 2008; Alliance Development Works, 2012; Damm, 2010; Eckert et al., 2012; González-Riancho et al., 2014; etc.). The selected vulnerability indicators differ among authors and are based on previous literature, scientific knowledge and advances, lessons learned from tsunami disasters, the study scope and the availability of information. The ideas and concepts measured by all those indicators are, however, very similar.

The aim of this work is to understand whether the scientific community is proposing the right indicators to measure human vulnerability in light of past tsunami impacts. Accordingly, it focuses on the analysis of past tsunami events to understand and integrate the vulnerability conditions that worsened the tsunami human impacts. The specific objectives of this paper are to (i) compile some of the indicators currently applied to assess human vulnerability to the tsunami hazard and, based on them, propose a general scheme to homogenize tsunami human vulnerability concepts and indicators; (ii) validate the indicators as far as possible through available data from past tsunami events; and (iii) identify new indicators or approaches through the evidences detected in those past tsunami events.

\section{Review of existing tsunami human vulnerability indicators}

A comprehensive review of the existing works on tsunami vulnerability assessment based on indicators has been carried out to identify those currently used to assess human vulnerability. Although the various authors propose and apply different indicators according to the scope of their work and the available information, all of the applied exposure and vulnerability indicators follow specific thematic areas and can be grouped within four main categories and 10 key issues. The four categories are: exposure, warning capacity, evacuation and emergency capacity and recovery capacity. The 10 key issues are: (i) human exposure, (ii) reception of a warning message, (iii) understanding of a warning message, (iv) mobility and evacuation speed, (v) safety of buildings, (vi) difficulties in evacuation related to built environment, (vii) society's coping capacity, (viii) household economic resources, (ix) recovery external support and (x) expected impacts affecting recovery. Table 1 summarizes the compiled indicators, which are organized within the proposed vulnerability categories/key issues/indicators scheme, detailing the sources that applied them in previous works.

\section{Validation of existing indicators through past tsunami events}

To validate the indicators presented in Table 1 , the impacts generated in several countries (Japan, Chile, Samoa, Sri Lanka and Thailand) by different past tsunami events are evaluated. The events analysed are the 2011 Great Tohoku tsunami, the 2010 Chilean tsunami, the 2009 Samoan tsunami and the 2004 Indian Ocean tsunami; their main characteristics are presented in Table 2 . The validation is based on the comparison of the tsunami impacts on the population with the available census data of each country previous of each event to understand if the tsunami mortality trends are related to the event itself or to pre-tsunami existing population patterns and vulnerability characteristics. To do that, the pre- and post-tsunami official censuses are analysed for the various countries (Japan: Japan Statistics Bureau, 2010, and National Police Agency of Japan, 2014; Chile: Instituto Nacional de Estadísticas de Chile, 2002, and Fiscalía Nacional de Chile, 2011; Samoa: Samoa Bureau of Statistics, 2008, and Government of Samoa, 2010; Sri Lanka: Department of Census and Statistics of Sri Lanka, 2001 and 2004; and Thailand: Asian Disaster Preparedness Center, 2007). Table 3 summarizes the indicators presented in Table 1 that can be validated in this work based on the information provided by these sources.

The following subsections present the validation of the indicators based on the available information. It is important here to point out some assumptions and/or limitations concerning the data and some sources of information. (1) Each indicator will be validated according to the information available, which means that not every indicator can be validated in every country. For example, the indicator age will be contrasted for four countries, while some aspects related to the safety of buildings will only be analysed in Sri Lanka. (2) Although the tsunami censuses usually differentiate between fatalities (dead) and missing persons, this study will consider and analyse the sum of both categories as total casualties. (3) The different number of victims in Japan or Sri Lanka (between 14000 and 19000 people) and Chile or Samoa (fewer than 200 people) makes it necessary to accept some statistical limitations regarding the latter countries (Chile and Samoa). (4) Regarding Sri Lanka, the age of tsunami victims over 30 years old is not available disaggregated in ranges of 
Table 1. Review of existing indicators and new framework for tsunami human vulnerability.

\begin{tabular}{|c|c|c|c|}
\hline Categ. & Key issues & Review of currently applied tsunami human vulnerability indicators & Sources* \\
\hline $\begin{array}{l}\text { Expo- } \\
\text { sure }\end{array}$ & $\begin{array}{l}\text { I. Human } \\
\text { exposure }\end{array}$ & $\begin{array}{l}\text { Number of people exposed } \\
\text { Population density } \\
\text { Housing density }\end{array}$ & $\begin{array}{l}{[1,3,4,8]} \\
{[1 b, 9]} \\
{[9]}\end{array}$ \\
\hline \multirow[t]{2}{*}{$\begin{array}{l}\text { Warning } \\
\text { capacity }\end{array}$} & $\begin{array}{l}\text { II. Reception of } \\
\text { a warning } \\
\text { message }\end{array}$ & $\begin{array}{l}\text { Isolated communities } \\
\text { Early warning system (EWS) } \\
\text { Access to specific means of communication }\end{array}$ & $\begin{array}{l}{[3]} \\
{[3]} \\
{[7]}\end{array}$ \\
\hline & $\begin{array}{l}\text { III. } \\
\text { Understanding } \\
\text { of a warning } \\
\text { message }\end{array}$ & $\begin{array}{l}\text { Age } \\
\text { Education level } \\
\text { Illiteracy } \\
\text { Immigration } \\
\text { Language skills } \\
\text { Ethnicity } \\
\text { Social and institutional awareness }\end{array}$ & $\begin{array}{l}{[1,3,7]} \\
{[1,1 \mathrm{~b}, 7]} \\
{[1,3]} \\
{[1,1 \mathrm{~b}]} \\
{[2,7]} \\
{[5]} \\
{[3,7]}\end{array}$ \\
\hline \multirow[t]{4}{*}{$\begin{array}{l}\text { Evacuation } \\
\text { and } \\
\text { emergency } \\
\text { capacity }\end{array}$} & $\begin{array}{l}\text { IV. Mobility } \\
\text { and evacuation } \\
\text { speed }\end{array}$ & $\begin{array}{l}\text { Age } \\
\text { Gender } \\
\text { Disability } \\
\text { Health } \\
\text { Dependency }\end{array}$ & $\begin{array}{l}{[1,1 b, 2,3,4,7]} \\
{[2,5,7]} \\
{[1 b, 2,3,4,7]} \\
{[7]} \\
{[7]}\end{array}$ \\
\hline & $\begin{array}{l}\text { V. Safety of } \\
\text { buildings }\end{array}$ & $\begin{array}{l}\text { Type of building } \\
\text { Building materials } \\
\text { Building conditions } \\
\text { Number of floors } \\
\text { Isolate buildings } \\
\text { Elevation } \\
\text { Shoreline distance }\end{array}$ & $\begin{array}{l}{[2,6,8]} \\
{[3,4,5]} \\
{[4]} \\
{[3,4,6]} \\
{[4]} \\
{[6]} \\
{[6]}\end{array}$ \\
\hline & $\begin{array}{l}\text { VI. Difficulties } \\
\text { in evacuation } \\
\text { related to } \\
\text { buil } \\
\text { environment }\end{array}$ & $\begin{array}{l}\text { Distance to safe places: evacuation, isolated communities, access to main roads } \\
\text { Critical buildings: schools, hospitals, hotels, malls, etc. } \\
\text { Number of people in critical buildings } \\
\text { Critical infrastructure: road network } \\
\text { Critical infrastructure: hazardous/dangerous infrastructures } \\
\text { Vertical evacuation: number of floors }\end{array}$ & $\begin{array}{l}{[3,7]} \\
{[1 b, 3,4]} \\
{[3]} \\
{[3,7]} \\
{[3]} \\
{[1,1 b, 3,7]}\end{array}$ \\
\hline & $\begin{array}{l}\text { VII. Society's } \\
\text { coping capacity }\end{array}$ & $\begin{array}{l}\text { Emergency and health infrastructures } \\
\text { Health capacity: number of hospital beds, density of medics } \\
\text { Social and institutional awareness } \\
\text { EWS, hazard maps, evacuation routes/drills } \\
\text { Local civil protection commissions, contingency plans, coordination networks, } \\
\text { emergency human resources }\end{array}$ & $\begin{array}{l}{[1 b, 3]} \\
{[1 b]} \\
{[3,7]} \\
{[3]} \\
{[3]}\end{array}$ \\
\hline \multirow[t]{3}{*}{$\begin{array}{l}\text { Recovery } \\
\text { capacity }\end{array}$} & $\begin{array}{l}\text { VIII. Household } \\
\text { economic } \\
\text { resources }\end{array}$ & $\begin{array}{l}\text { Income, savings, poverty } \\
\text { Economic dependency ratio: male dependency } \\
\text { Ownership, tenure: land, housing, car } \\
\text { Employment, type of occupation } \\
\text { Insurance: health, house }\end{array}$ & $\begin{array}{l}{[1 \mathrm{~b}, 2,3,7,9]} \\
{[1,1 \mathrm{~b}]} \\
{[2,7]} \\
{[1 \mathrm{~b}, 2,7]} \\
{[2,7]}\end{array}$ \\
\hline & $\begin{array}{l}\text { IX. Recovery } \\
\text { external } \\
\text { support }\end{array}$ & $\begin{array}{l}\text { Basic services availability: water/electricity supply, emergency/health infrastructures } \\
\text { Access to social networks of mutual help: neighbourhood, family, formal and informal institutions } \\
\text { Temporary shelters, public funds, catastrophe insurance, medical/public health human resources, } \\
\text { development human resources }\end{array}$ & $\begin{array}{l}{[1 \mathrm{~b}, 3]} \\
{[1 \mathrm{~b}, 2,7]} \\
{[3]}\end{array}$ \\
\hline & $\begin{array}{l}\text { X. Expected } \\
\text { impacts } \\
\text { affecting } \\
\text { recovery }\end{array}$ & $\begin{array}{l}\text { Human: injuries, degree of damage experienced } \\
\text { Socioeconomic: loss of jobs/livelihoods, loss of contribution to GDP/foreign trade, affected } \\
\text { local income source, job diversity } \\
\text { Environmental: loss of sensitive ecosystems and ecosystem services } \\
\text { Infrastructures: residence/building damage, cascading impacts related to } \\
\text { dangerous/hazardous infrastructures } \\
\text { Cultural: cultural heritage }\end{array}$ & $\begin{array}{l}{[2,7]} \\
{[1 b, 3,7]} \\
{[3]} \\
{[2,3,5]} \\
{[1 b]}\end{array}$ \\
\hline
\end{tabular}

al. (2006a, b): HAZUS-MH model; [6] Eckert et al. (2012); [7] Post et al (2009); [8] Koeri (2009) ; [9] Wijetunge (2013); [10] Ruangrassamee et al. (2006). 
Table 2. Description of the past tsunami events used to validate the human vulnerability indicators.

\begin{tabular}{|c|c|c|c|c|}
\hline & $\begin{array}{l}2011 \text { Great Tōhoku } \\
\text { tsunami }\end{array}$ & $\begin{array}{l}2010 \text { Chilean } \\
\text { tsunami }\end{array}$ & $\begin{array}{l}2009 \text { Samoan } \\
\text { tsunami }\end{array}$ & $\begin{array}{l}2004 \text { Indian Ocean } \\
\text { tsunami }\end{array}$ \\
\hline Date $^{1}$ & 11 Mar 2011 (Friday) & 27 Feb 2010 (Saturday) & 29 Sep 2009 (Tuesday) & 26 Dec 2004 (Sunday) \\
\hline EQ magnitude ${ }^{1}$ & $9.0 \mathrm{Mw}$ & $8.8 \mathrm{Mw}$ & $8.1 \mathrm{Mw}$ & $9.1 \mathrm{Mw}$ \\
\hline EQ epicentre ${ }^{1}$ & $\begin{array}{l}38.30^{\circ} \mathrm{N}, 142.37^{\circ} \mathrm{E} \\
(70 \mathrm{~km} \text { E of Oshika } \\
\text { Peninsula, Tōhoku) }\end{array}$ & $\begin{array}{l}36.12^{\circ} \mathrm{S}, 72.90^{\circ} \mathrm{W} \\
(12.5 \mathrm{~km} \text { from Chilean } \\
\text { coast })\end{array}$ & $\begin{array}{l}15.49^{\circ} \mathrm{S}, 172.09^{\circ} \mathrm{W} \\
(190 \mathrm{~km} \mathrm{~S} \text { of Apia, } \\
\text { Samoa) }\end{array}$ & $\begin{array}{l}3.30^{\circ} \mathrm{N}, 95.98^{\circ} \mathrm{E}(250 \mathrm{~km} \mathrm{SSE} \text { of } \\
\text { Banda Aceh, Sumatra, Indonesia) }\end{array}$ \\
\hline EQ hypocentre $^{1}$ & $29 \mathrm{~km}$ & $22.9 \mathrm{~km}$ & $18 \mathrm{~km}$ & $30 \mathrm{~km}$ \\
\hline EQ time ${ }^{1}$ & 05:46:24 UTC & 06:34:11 UTC & 17:48:10 UTC & 00:58:53 UTC \\
\hline $\begin{array}{l}\text { Countries mainly } \\
\text { affected }\end{array}$ & Japan, Pacific Rim & Chile & $\begin{array}{l}\text { Samoa, American } \\
\text { Samoa, Tonga, French } \\
\text { Polynesia, Cook Islands, } \\
\text { Fiji, New Zealand }\end{array}$ & $\begin{array}{l}\text { Indonesia, Sri Lanka, India, Thai- } \\
\text { land, Maldives, Somalia, Malaysia, } \\
\text { Myanmar, Tanzania, Seychelles, } \\
\text { Bangladesh, Kenya }\end{array}$ \\
\hline Country analysed & Japan & Chile & Samoa & Sri Lanka (SL), Thailand (TH) \\
\hline $\begin{array}{l}\text { Regions mainly affected } \\
\text { in the country }{ }^{3}\end{array}$ & $\begin{array}{l}\text { Tohoku Region }(\mathrm{T}) \text { : } \\
\text { Iwate, Miyagi and } \\
\text { Fukushima }\end{array}$ & $\begin{array}{l}\text { Valparaíso, O’Higgins, } \\
\text { Maule, Biobío }\end{array}$ & $\begin{array}{l}\text { Poutasi, Saleapaga, } \\
\text { Lalomanu, Satitoa, } \\
\text { Malaela }\end{array}$ & $\begin{array}{l}\text { SL: Jaffna, Mullaitivu, Trincoma- } \\
\text { lee, Batticaloe, Ampara, Hambatota, } \\
\text { Matara, Galle; TH: Ranong, Phang } \\
\text { Nga, Phuket, Krabi, Trang }\end{array}$ \\
\hline EQ LT & 14:46:24 JST & 03:34:11 CLT & 06:48:10 WST & $\begin{array}{l}\text { 06:28:53 IST (SL) } \\
\text { 08:28:53 ICT (TH) }\end{array}$ \\
\hline TS arrival time & 20 min after the $\mathrm{EQ}^{4}$ & 30 min after the $\mathrm{EQ}^{5}$ & $\begin{array}{l}15-20 \text { min after the } \\
\mathrm{EQ}^{7,8}\end{array}$ & $2 \mathrm{~h}(\mathrm{SL})$ and $1 \mathrm{~h}(\mathrm{TH})$ after the EQ \\
\hline $\begin{array}{l}\text { EWS (local warning } \\
\text { issued) }\end{array}$ & Yes & No & Yes (not enough time) ${ }^{9}$ & No \\
\hline $\begin{array}{l}\text { TS maximum wave } \\
\text { height (tide gauges) }\end{array}$ & $\begin{array}{l}7.3 \mathrm{~m} \text { (Soma, } \\
\text { Fukushima }^{2}\end{array}$ & $2.61 \mathrm{~m}$ (Valparaíso) $^{1}$ & $2.5 \mathrm{~m}$ (Pago Pago $)^{7}$ & $\begin{array}{l}\text { SL: } 3.87 \mathrm{~m} \text { (Colombo }^{11} \\
\text { TH: } 4.70 \mathrm{~m} \text { (Ta Phao Noi) }^{13}\end{array}$ \\
\hline $\begin{array}{l}\text { TS maximum inundation } \\
\text { depth (surveys) }\end{array}$ & $10-15 \mathrm{~m}(\text { Sanriku })^{4}$ & $2.30 \mathrm{~m}$ (Constitución) ${ }^{6}$ & Above $5 \mathrm{~m}^{9,10}$ & $\begin{array}{l}\text { SL: above } 10 \mathrm{~m} \text { (Ampara) }^{12} \\
\text { TH: } 6 \mathrm{~m} \text { (Ban Thale Nok) }^{13}\end{array}$ \\
\hline $\begin{array}{l}\text { TS maximum run-up } \\
(\text { a.s.l. })^{2}\end{array}$ & $\begin{array}{l}55.88 \mathrm{~m} \text { (Iwate) } \\
38.56 \mathrm{~m} \text { (Miyagi), }\end{array}$ & 29 m (Constitución $)^{2,5}$ & $\begin{array}{l}14.45 \mathrm{~m} \text { (Lepa, Upolu } \\
\text { Island) }\end{array}$ & $\begin{array}{l}\text { SL: } 12.50 \mathrm{~m} \text { (Yala) } \\
\text { TH: } 19.60 \mathrm{~m} \text { (Ban Thung Dap) }\end{array}$ \\
\hline $\begin{array}{l}\text { TS maximum distance } \\
\text { travelled inland }{ }^{2}\end{array}$ & $\begin{array}{l}7900 \mathrm{~m} \text { (Iwate) } \\
4951 \mathrm{~m} \text { (Miyagi), }\end{array}$ & 1032 m (Playa Purema) & $\begin{array}{l}440 \mathrm{~m} \text { (Salani, Upolu } \\
\text { Island) }\end{array}$ & $\begin{array}{l}\text { SL: } 500 \mathrm{~m} \text { (Koggala and Kalkudah) } \\
\text { TH: } 939 \mathrm{~m} \text { (Hat Praphat) }\end{array}$ \\
\hline Fatalities $^{3}$ & 15884 (T: 15817$)$ & 156 & 140 & SL: 13 391; TH: 5395 \\
\hline Missing $^{3}$ & 2633 (T: 2629) & 25 & 4 & SL: 799; TH: N/A \\
\hline Total casualties ${ }^{3}$ & 18517 (T: 18446) & 181 & 144 & SL: 14 190; TH: 5395 \\
\hline
\end{tabular}

10 years. The 2001 census data do not cover the Tamil areas (north and east), which were highly affected by the tsunami, due to the security situation in the country at that time. For this reason, it is not always possible to compare pre-and posttsunami data about the northern province districts, namely, Jaffna, Killinochchi, Mullativu, Trincomalee and Baticaloe. (5) Regarding Japan, the unknown gender and unknown age victims have been excluded from the total number of deaths in Iwate, Miyagi and Fukushima prefectures by the Japanese authorities responsible. Therefore, 15331 of a total of 15817 victims are analysed in this work $(97 \%)$.
Despite these limitations, the quality of the databases applied in this work is good enough and helped generate wellfounded, conclusive and useful information to validate the various indicators.

\subsection{Human exposure}

Different approaches are applied in literature to understand the potential human exposure to a tsunami hazard. Several authors base the hazard assessment on numerical modelling of the tsunamigenic sources to identify the potential flooded area and subsequent number of people located there (UNU- 
Table 3. Indicators validated in this paper based on available information; V: indicators validated, NV: indicators not validated although the information is available, since the countries did not issue a tsunami warning before the first wave reached the coastline.

\begin{tabular}{|c|c|c|c|c|c|c|}
\hline $\begin{array}{l}\text { Tsunami human } \\
\text { vulnerability } \\
\text { key issues }\end{array}$ & Indicators & $\begin{array}{l}\text { Japan } \\
2011\end{array}$ & $\begin{array}{l}\text { Chile } \\
2010\end{array}$ & $\begin{array}{l}\text { Samoa } \\
2009\end{array}$ & $\begin{array}{l}\text { Sri Lanka } \\
2004\end{array}$ & $\begin{array}{l}\text { Thailand } \\
2004\end{array}$ \\
\hline \multirow{2}{*}{$\begin{array}{l}\text { I. Human } \\
\text { exposure }\end{array}$} & Number of people exposed & $\mathrm{V}$ & $\mathrm{V}$ & & $\mathrm{V}$ & \\
\hline & Population density & $\mathrm{V}$ & $\mathrm{V}$ & & $\mathrm{V}$ & \\
\hline $\begin{array}{l}\text { II. Reception of } \\
\text { a warning message }\end{array}$ & Early warning system & YES & NO & YES & NO & NO \\
\hline \multirow{6}{*}{$\begin{array}{l}\text { III. } \\
\text { Understanding } \\
\text { of a } \\
\text { warning } \\
\text { message }\end{array}$} & Age & $\mathrm{V}$ & NV & NV & NV & \\
\hline & Education level & & & & NV & \\
\hline & Illiteracy & & & & NV & \\
\hline & Immigration & & & & NV & \\
\hline & Language skills & & & & NV & \\
\hline & Ethnicity & & & & NV & \\
\hline \multirow{4}{*}{$\begin{array}{l}\text { IV. Mobility } \\
\text { and evacuation } \\
\text { speed }\end{array}$} & Age & $\mathrm{V}$ & $\mathrm{V}$ & V & $\mathrm{V}$ & \\
\hline & Gender & $\mathrm{V}$ & $\mathrm{V}$ & $\mathrm{V}$ & $\mathrm{V}$ & \\
\hline & Disability & & & & $\mathrm{V}$ & \\
\hline & Dependency & $\mathrm{V}$ & $\mathrm{V}$ & V & $\mathrm{V}$ & \\
\hline \multirow{3}{*}{$\begin{array}{l}\text { V. Safety } \\
\text { of buildings }\end{array}$} & Type of building & & & & $\mathrm{V}$ & \\
\hline & Materials & & & & $\mathrm{V}$ & \\
\hline & Shoreline distance & & & & $\mathrm{V}$ & \\
\hline \multirow{2}{*}{$\begin{array}{l}\text { VIII. Economic } \\
\text { resources }\end{array}$} & Income, savings, poverty & & & & $\mathrm{V}$ & \\
\hline & Employment, type of occupation & & & & $\mathrm{V}$ & \\
\hline \multirow{2}{*}{$\begin{array}{l}\text { X. Expected impacts } \\
\text { affecting recovery }\end{array}$} & Socioeconomic: loss of jobs/livelihoods/GDP & & & & $\mathrm{V}$ & \\
\hline & Infrastructures (residence /building) damage & $\mathrm{V}$ & & & $\mathrm{V}$ & $\mathrm{V}$ \\
\hline
\end{tabular}

EHS, 2009; González-Riancho et al., 2014). When no numerical modelling is available, the human exposure assessment is usually based on the identification of a site-specific topographic contour line, the area below being assumed to be flooded (Sahal et al., 2013; Eckert et al., 2012; Suharyanto et al., 2012). For both approaches it is common to relate the human exposure to the number of people and population density by administrative unit (e.g. municipality, region).

The comparison between victims ratio (victims by administrative unit/total victims), population ratio (population by administrative unit/total population) and population density in the affected administrative units in Japan, Chile and Sri Lanka, i.e. prefectures, regions and districts, respectively, does not show a specific trend or relationship between these variables (Fig. 1). The correlation (Pearson coefficient, $r$ ) between the number of victims and the total population by analysis unit is $0.37,-0.06$ and -0.39 for Japan, Chile and Sri Lanka, respectively, while the correlation between the victims and population density is $0.76,0.48$ and -0.40 , respectively. Only Japan, where the tsunami travelled up to $10 \mathrm{~km}$ inland in some areas (Mori et al., 2012), shows some correlation between these variables, whilst being negative or very low for the other events.
More densely populated areas are supposed to have more people potentially affected if the area is exposed to the hazard; however, based on the post-tsunami census results it is not possible to connect high density units with potential high number of victims for every event. This would only be valid for events flooding huge coastal areas inland. Instead, population or population density in the exposed area might be a valid indicator. This statement is reinforced by some of the results provided in this article, such as those related to the distance to the sea. It can thus be asserted that for the identification of human exposure, some kind of numerical modelling is needed to calculate the potential exposed area, which will vary from one place to another depending on physical characteristics of the coastal zone and the hazard itself.

\subsection{Receiving and understanding a warning message}

A population that is not able to understand a warning message (not being able to read, not being able to speak the language or having intellectual limitations, for example) is more sensitive to the threat, as they will not be able to mobilize in a timely manner (UNU-EHS, 2009; Post et al., 2009; González-Riancho et al., 2014; etc.). Based on this idea, the indicators in Table 3 that could be validated in this section 

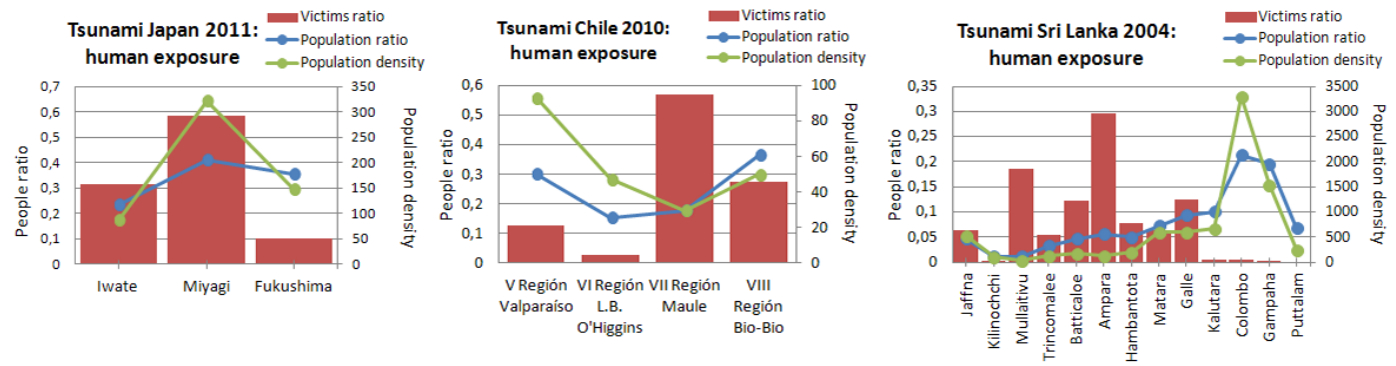

Figure 1. Correlation between tsunami victims ratio, population ratio and population density (tsunami events of Japan 2011 , Chile 2010 and Sri Lanka 2004).

are age, education level, literacy/illiteracy, immigration, language skills and ethnicity. However, although all this information is available for Sri Lanka and the age of the victims also for the other tsunami events, the fact of not having issued a warning in most of the cases cancels the possibility of validating the indicators. A summary of the tsunami warnings in all the analysed tsunami events is presented next.

The 2011 Tohoku earthquake happened at 14:46 JST (LT). The earthquake EWS sent out warnings 1 min before the earthquake was felt in Tokyo and the Japanese Meteorological Agency (JMA) issued a local tsunami warning 3 min after the quake struck. The tsunami first reached the Japanese mainland $20 \mathrm{~min}$ after the earthquake and ultimately affected a $2000 \mathrm{~km}$ stretch of Japan's Pacific coast (Mori et al., 2012). At 15:55 JST, the tsunami was observed flooding Sendai Airport (Gupta and Gahalaut, 2013). Residents of the hardest-hit areas only had around $15 \mathrm{~min}$ of warning (i.e. time left for evacuation), though Tokyo would have had at least $40 \mathrm{~min}$ of warning (MIT Technology review, 2015).

The earthquake that triggered the 2010 Chilean tsunami happened at 03:34 LT. An initial tsunami warning was issued for Chile by NOAA's Pacific Tsunami Warning Center $11 \mathrm{~min}$ after the earthquake and Chile's Servicio Hidrográfico y Oceanográfico de la Armada (SHOA) issued a tsunami warning within the same time frame. SHOA's warning however was cancelled shortly afterwards. Few coastal residents heard the warning or the cancellation due to widespread power outages and the official warning had little impact on survival (Dengler et al., 2012). This is also because the tsunami arrived within $30 \mathrm{~min}$ at many locations, and official evacuations and warnings by local authorities were often not in place prior to the arrival of the tsunami (Fritz et al., 2011).

The 2009 Samoan tsunamigenic earthquake happened at 06:48:11 LT, the Pacific Tsunami Warning Center (PTWC) in Hawaii issuing its first alert 16 min after the quake, the government of Samoa enacting then its own early warning protocols (UNESCO ITST Samoa, 2009). By that time the first tidal wave had crashed into villages and resorts in Samoa and American Samoa. Those who survived had already fled to higher land, rattled by powerful earth tremors lasting several minutes (UWI-CDEMA, 2010).
The earthquake that triggered the 2004 Indian Ocean tsunami happened at 06:28:53 and 08:28:53 in Sri Lanka and Thailand (LT), respectively. The first tsunami wave reached the coast at 08:30-08:45 in Sri Lanka and at 09:30 in Thailand (both LT). On 26 December 2004, there was no tsunami warning communication system in the Indian Ocean. A working tsunami warning system was established only for the Pacific where PTWC had the authority to issue the tsunami information. Unlike the Pacific, there were also very few real-time seismic data and no available sea level data from the Indian Ocean from which to confirm a tsunami and its size (Igarashi et al., 2011). It was then not possible to warn the population living in the coastal areas.

From the tsunami events analysed, Japan was the only country which had a proper early warning system, which helped to warn the population about the approaching tsunami just $3 \mathrm{~min}$ after the earthquake happened. This fact, together with the society's knowledge, awareness and preparedness against tsunami hazards helped to maximize the evacuees (Nakahara and Ichikawa, 2013). Most of those who did not succeed in evacuating in time were living in the hardesthit areas and had too little time (around $15 \mathrm{~min}$ ) to reach safe areas. Also, around $66 \%$ of the victims were above 60 years old, which indicates that when an early warning system properly works, special attention in vulnerability assessments must be paid to the elderly due to the difficulties they face in evacuating immediately and quickly. Regarding this age group, the age indicator is also associated with the capacity of understanding a warning message; however, the death rate cannot be assumed to be directly linked to this indicator. The difficulties found in validating the age in terms of understanding a warning message makes it necessary to recommend its use only as a mobility and evacuation speed indicator.

\subsection{Mobility and evacuation speed}

Human susceptibility relates to the predisposition of human beings to be injured or killed and encompasses issues related to deficiencies in mobility and differential weaknesses associated with gender, age or disabilities (Villagrán de León, 2008). The population with any mobility handicap is more 

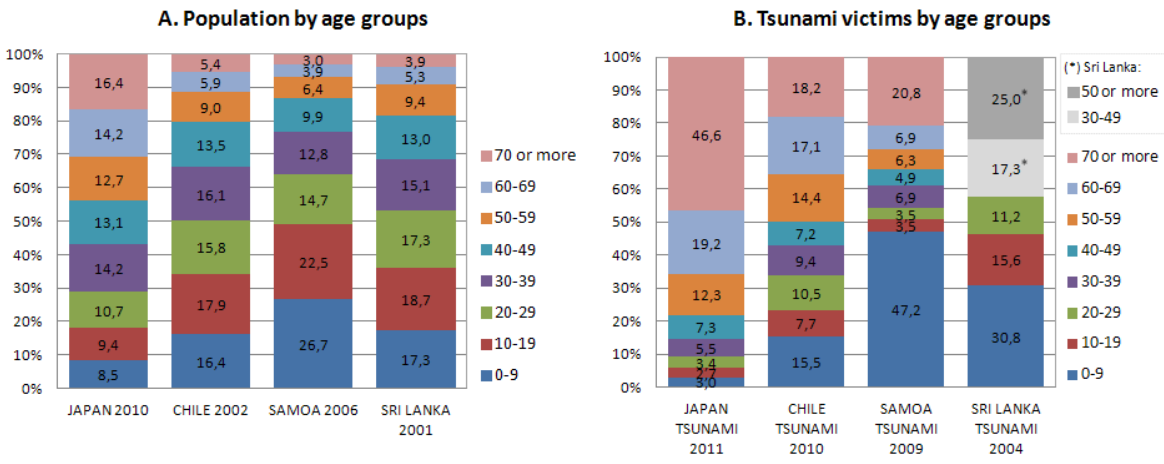

Figure 2. Age groups analysis (tsunami events of Japan 2011, Chile 2010, Samoa 2009 and Sri Lanka 2004): (a) pre-tsunami census, (b) tsunami victims. The age of tsunami victims over 30 years old in Sri Lanka is not available disaggregated in ranges of 10 years.

sensitive to a tsunami event in terms of evacuation, this being the case of people with health problems, disabilities, physical/intellectual limitations, the elderly and children, for example. These persons with greater difficulties in escaping will probably be supported by a family member, this fact being connected to concepts of gender and dependency, since in many countries it is the woman who normally deals with family members who have some type of limitation. This suggests that a slower small group of people composed of at least 2 or 3 persons will be generated around mobility handicapped people, the intrinsic sensitivity of the latter being transferred to his/her immediate surroundings. Therefore, the slow population is likely to endanger other people trying to help them, as all of them will have less time for evacuation. This should be considered when identifying the vulnerable population. According to this idea, and based on the indicators presented in Table 3, age, gender, disability and dependency indicators are analysed and validated in this section.

\subsubsection{Age}

Most of the authors highlight the age groups including the elderly and children as being sensitive to possible tsunami events due to difficulties in both mobility and evacuation speed. The chosen age ranges in the diverse works vary according to the information available for each case study (i.e. census data). Most of the post-tsunami reports (Mazurana et al., 2011; government of Japan, 2012; etc.) confirm higher mortality associated with these groups. Rofi et al. (2006) found that it was primarily people aged 9 years and younger and 60 years and older who were killed in Indonesia's Aceh Barat and Nagan Raya districts during the tsunami in 2004. UNFPA (2005) stated that the majority of survivors in tsunami-affected villages in Nanggroe Aceh Darussalam province, both male and female, were in the teenage and adult range of 15-45 perhaps because they were physically and mentally strong enough to survive the tsunami and the post-tsunami period. Nakahara and Ichikawa (2013) stated that whereas studies in Indonesia and Sri Lanka (In- dian Ocean Tsunami 2004) reported higher mortality rates among children, the elderly and women, the 2011 tsunami in Japan is characterized by lower mortality rates among children, increased mortality rates with age and no mortality differences between the sexes, perhaps due to the existence of a better tsunami warning system. The higher mortality pattern among the elderly in Aceh province, Indonesia, highlights the difficulties had in evacuating promptly or being able to withstand the force of the tsunami (Doocy et al., 2007).

In order to better understand the real mortality patterns, Fig. 2 jointly analyses the percentage of human losses by age group for the four tsunami events (Fig. 2b), together with the age group structure in the country before each event, based on the immediately preceding census (Fig. 2a). The tsunami victims graph shows higher mortality percentages associated with older people and children. However, mortality percentages vary substantially among countries. Focusing on the pre-tsunami census graph, three different country profiles can be distinguished according to their development level. Japan is a developed and aged country with $43.4 \%$ of the population over 50 years old and $17.9 \%$ below 20 years old; Samoa, as an undeveloped country, has a younger population, with $13.3 \%$ over 50 years old and $49.2 \%$ below 20 years old; and both Chile and Sri Lanka, as developing and "medium-aged" countries, have an intermediate profile with around $19 \%$ over 50 years old and around $35 \%$ below 20 years old.

The higher or lesser percentages for the mentioned age groups are associated with these country development profiles and will explain some of the age-related tsunami human impacts. Thus, an aged country like Japan had a much higher percentage of victims among people of 50 or more years old ( $78.1 \%$ ); a young country like Samoa in the age groups 0 9 years $(50.7 \%)$ and 60 years or more $(34 \%)$; Chile and Sri Lanka having intermediate values for both age groups. Compared to Chile, Sri Lanka had a higher death toll among children, maybe due to the timing of the tsunami. This age group analysis shows that even if higher mortality rates are found in older people and children, special attention should be paid 
to the whole profile of the country and the structure of the population before an event.

Figure $3 \mathrm{c}$ and Table 4 show the death rate ratios (DRR) by age groups and for the four tsunami events. The DRR is calculated by dividing the percentage of tsunami victims (Fig. 3b) by the percentage of population for each age group (Fig. 3a). The result provided is the factor by which one must multiply the percentage of each population age group, to estimate the expected percentage of victims in that group. The points located above the DRR with value 1 imply that the death related to these age groups is associated with a higher vulnerability to the tsunami event and not to the pre-event structure of the population. The most vulnerable age groups are those below 10 years old and above 60 years old. Age groups above 60 years old are always, for all the tsunami cases, amplifying their percentage in terms of victims, the DRR increasing with age. The DRR is between 0.96 and 1.60 for the age group 50-59, between 1.35 and 2.88 for the age group 60-69 years old and between 2.84 and 6.88 for people above 70 years old. The DRR of children ( $0-9$ years old) is lower than for the elderly, being between 0.36 and 1.78. For the age groups between 10 and 49 the ratio varies between 0 and 1 for all countries and events, indicating that the percentage of expected victims in each of these age groups is less than the percentage given by the census, regardless of the development profile of the country.

The percentages of child victims for the four events show a range that goes from $3 \%$ in Japan to $47 \%$ in Samoa. Children, as a dependent group, are particularly sensitive to the timing of the tsunami as it determines their potential location and company, at school with teachers, at home with family, or playing with other children in the street, for example. According to Table 2, the approximate timing of each event was: Friday at 3 p.m. (Japan), Saturday at 3.50 a.m. (Chile), Tuesday at 7.15 a.m. (Samoa), Sunday at 8.28 a.m. (Sri Lanka) and Sunday at 9.28 a.m. (Thailand). Only Japan received the tsunami on a weekday during working hours; this may be the reason for the low mortality in children. Nakahara and Ichikawa (2013) corroborates this idea suggesting that the timing of the tsunami might have influenced age-sex mortality patterns. While the 2004 Indian Ocean tsunami hit rural communities on Sunday morning, when children and women were at home but men were working away from home (e.g. engaged in offshore fishing), the 2011 Japan tsunami hit communities in the afternoon on a weekday, when children were attending school or kindergarten. The high tsunami preparedness and awareness of the Japanese society indicates that schools might have provided adequate protection and evacuation, justifying the low child mortality rate.

Literature on vulnerability assessments shows that the indicators which measure sensitive age groups, specifically children, vary a lot according to the census information available in each case study. Thus, several age groups have been proposed to be considered as sensitive: children below 5 years old (Dwyer et al., 2004; Grezio et al., 2012), below 6 years old (UNU-EHS, 2009), below 10 years old (González-Riancho et al., 2014), etc. However, the analysis of child-related age groups, i.e. 0-4 and 5-9 year olds, for the tsunami events studied in this work, does not show a clear pattern when comparing pre- and post-tsunami censuses (Fig. 4). The pre-tsunami child population is quite homogeneous, i.e. the four countries having around $50 \%$ of both age groups. The tsunami victims show a homogeneous distribution in Japan and Sri Lanka, this not being the case for Chile and Samoa. Nonetheless it should be acknowledged that the small size of both Chile and Samoa samples (28 and 68 child victims, respectively) could affect the presented result, since Japan and Sri Lanka (466 and 4368 child victims respectively) show similar percentages to the pre-tsunami census. Focusing on the latter, both age groups could be assumed to be similarly vulnerable in terms of the number of victims and could jointly be assessed (i.e. $0-9$ years) in future vulnerability assessment studies.

\subsubsection{Gender}

As far as the gender indicator is concerned, the South Asian Disaster Knowledge Network (SADKN) defines the word "gender" as a cultural construct consisting of a set of distinguishable characteristics, roles and tasks associated with each biological sex ${ }^{1}$.

This term is mainly associated with women in disaster risk management, as women tend to be at a more disadvantageous position in society as compared to men. Several post-tsunami reports in different countries pointed out the higher death rate among women. For the Indian Ocean tsunami (2004), surveys carried out by Oxfam in villages in Aceh Besar and North Aceh districts (Indonesia) confirmed higher mortality rates 4 times higher among females (Oxfam, 2005). Rofi et al. (2006) found that two-thirds of those who died in Indonesia's Aceh Barat and Nagan Raya districts (Aceh province) were female. Oxfam (2005) mentions the massive and disproportionate toll that the tsunami took on the women of Sri Lanka, cutting across ethnic lines. Regarding the east Japan disaster (earthquake and tsunami), Saito (2012) stated that in the areas that were worst affected by the disaster, women made up $54 \%$ of deaths. In Tohoku, gender roles remain very traditional and women are seen as responsible for taking care of other family members (Saito, 2012). Villagrán de León (2008) stated that, according to Guha-Sapir et al. (2006) and Birkmann (2006), in the case of tsunamis, women, children and elderly persons are more vulnerable than men. According to these results, most of the authors use gender as an indicator for tsunami vulnerability assessments (see Table 1).

Oxfam (2005) explained the gender results in various countries affected by the 2004 Indian Ocean tsunami stating

\footnotetext{
${ }^{1}$ http://www.saarc-sadkn.org/theme_social_gender.aspx (last access: 21 May 2015)
} 

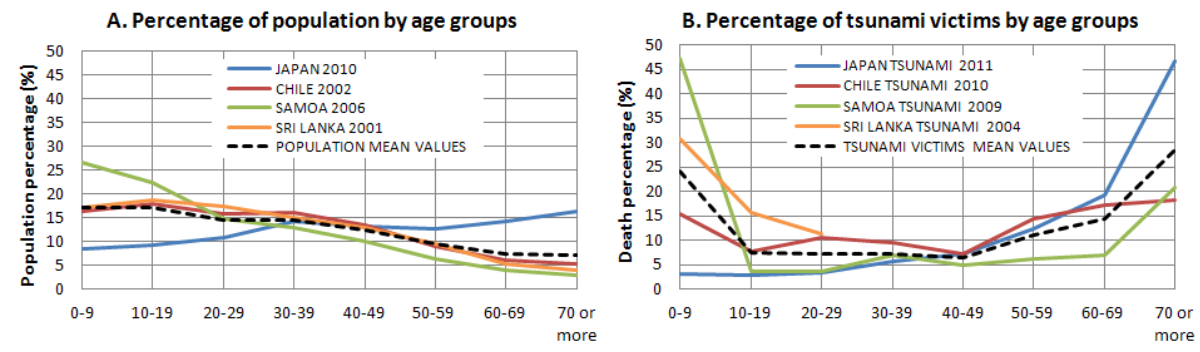

C. Tsunami death rate ratio by age groups

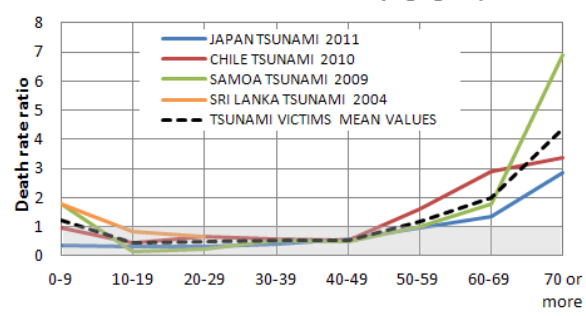

Figure 3. Analysis of mortality by age group (tsunami events of Japan 2011, Chile 2010, Samoa 2009 and Sri Lanka 2004) according to (a) pre-tsunami census; (b) tsunami victims and (c) tsunami death rate ratio $(C=B / A)$. The age of tsunami victims over 30 years old in Sri Lanka is not available disaggregated in ranges of 10 years, consequently this age range is not represented in the graph. The mean values for this age range are calculated considering only the other three tsunami events.

Table 4. Tsunami death rate ratios (Japan 2011, Chile 2010, Samoa 2009 and Sri Lanka 2004). The age of tsunami victims over 30 years old in Sri Lanka is not available (N/A) disaggregated in ranges of 10 years; consequently the mean value for this age range is calculated considering only the other three tsunami events.

\begin{tabular}{cccccc}
\hline \multicolumn{7}{c}{ Tsunami death rate ratios } \\
\hline Age groups & 2011 Japan & 2010 Chile & 2009 Samoa & 2004 Sri Lanka & Mean \\
\hline $0-9$ & 0.36 & 0.95 & 1.77 & 1.78 & 1.21 \\
$10-19$ & 0.29 & 0.43 & 0.15 & 0.83 & 0.43 \\
$20-29$ & 0.31 & 0.66 & 0.24 & 0.65 & 0.46 \\
$30-39$ & 0.39 & 0.58 & 0.54 & N/A & 0.51 \\
$40-49$ & 0.56 & 0.53 & 0.49 & N/A & 0.53 \\
$50-59$ & 0.96 & 1.60 & 0.98 & N/A & 1.18 \\
$60-69$ & 1.35 & 2.88 & 1.77 & N/A & 2.00 \\
70 or more & 2.84 & 3.37 & 6.88 & N/A & 4.36 \\
\hline
\end{tabular}

that (1) while males were working either fishing far out at sea or out in agricultural fields or markets, women and children stayed at home; (2) the sheer strength needed to stay alive in the torrent was also often decisive in determining who survived; many women and young children were unable to stay on their feet or afloat in the powerful waves and were simply tired and therefore drowned; (3) women clinging to one or more children would have tired even more quickly and (4) the skills that helped people survive the tsunami, especially swimming and tree climbing, are taught to male children in Sri Lanka to perform tasks that are done nearly exclusively by men. These four explanations respond to different aspects to be considered in future vulnerability assessments: probability and vulnerability. On the one hand, the probability of being affected should be analysed for each study area and requires understanding the site-specific cul- tural traditions to correctly measure the temporal exposure (e.g. women and children at the beach on a Sunday morning while men are working). On the other hand, it is essential to understand the vulnerability of specific sectors of society such as women and children due to their intrinsic characteristics (i.e. less physical strength) or to gender-related roles (i.e. family care roles, dependency and specific skills like swimming).

The next analyses aim to confirm whether the number of female victims is always higher and whether the assumptions that assign higher vulnerability to women due to gender roles are acceptable for every tsunami case. Figure 5 shows the human losses by sex for several tsunami events, together with the population structure in the country before the event, based on the immediately preceding census. Higher percentages of female victims are found in most of the events except 

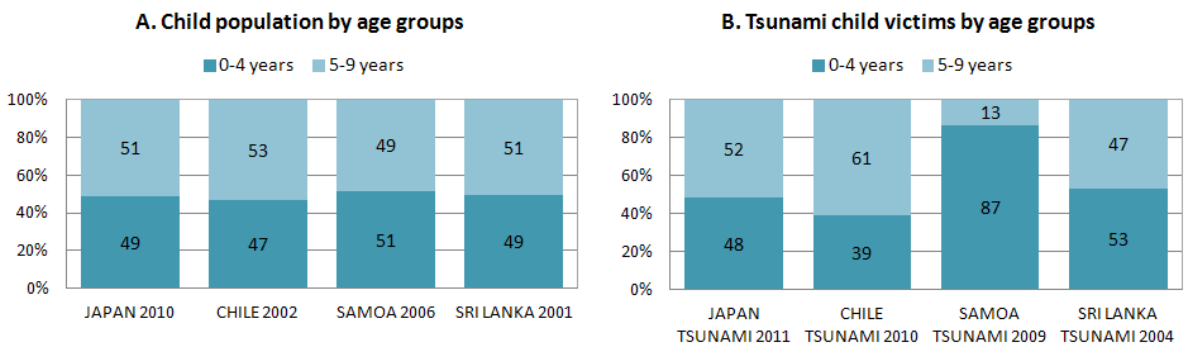

Figure 4. Analysis of child age groups (tsunami events of Japan 2011, Chile 2010, Samoa 2009 and Sri Lanka 2004) according to (a) pretsunami census data and (b) data on tsunami victims.
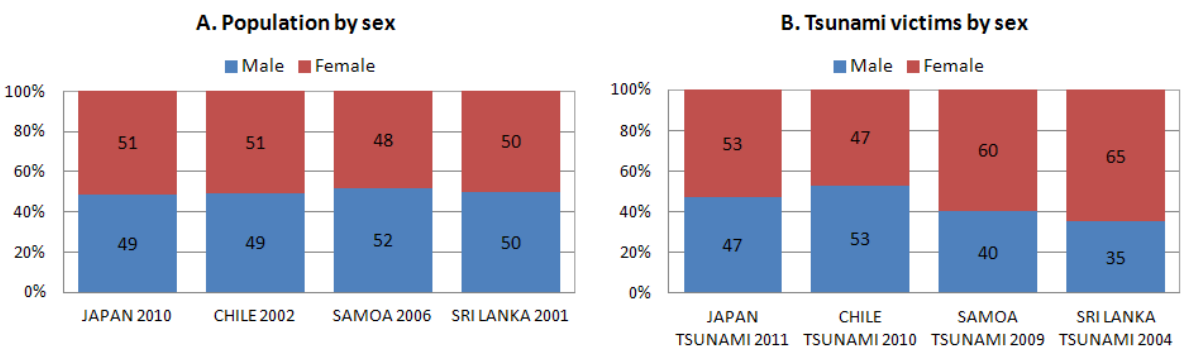

Figure 5. Gender analysis (tsunami events of Japan 2011, Chile 2010, Samoa 2009 and Sri Lanka 2004) according to (a) pre-tsunami census data and (b) data on tsunami victims.

Chile, even when the population distribution in the country before the tsunami is male-predominant, such as in Samoa. The percentage of female victims is higher when the country is less developed and might be related to dependency and gender roles. However, to understand the reasons conditioning the higher female mortality, it is essential to analyse this information in an age-disaggregated format. Figure 6 shows the population pyramids for the four countries and both preand post-tsunami censuses, illustrating the distribution of age groups by sex.

As far as the age analysis in Fig. 6 is concerned, the pre-tsunami graphs on the left confirm the previous classification of the countries according to development profiles: (i) Japan as an aged country with a contracting pyramid typical of developed countries with negative or no growth, population generally older on average, indicating long life expectancy and low death and birth rates; (ii) Chile/Sri Lanka with stationary pyramids typical of developing countries that tend to ageing and have finished their demographic transition; and (iii) Samoa as a young country, with an expanding population pyramid that is very wide at the base, indicating high birth and death rates, typical of undeveloped countries. The post-tsunami graphs on the right show a coherent classification pattern: (i) Japan has the highest mortality among the age group of over 60 year olds; (ii) Chile and Sri Lanka show quite a homogeneous distribution among age groups with high mortality among the elderly and children; and (iii) Samoa presents very high mortality among children and a high mortality among the elderly. These results of age analysis are summarized in Fig. 7 which presents population rates and tsunami mortality rates by age and type of population pyramid.

Back to Fig. 6 and focusing now on the gender analysis, the high female mortality rate in Japan is mainly attributed to elderly females of 70 years old or more, this being an understandable distribution considering the high number of women in Japan in that age range, shown in the Japan census 2010 graph. Therefore, the number of female victims in Japan is not a matter of gender, in terms of less resistance to tsunami for example, but a matter of probability due to female longevity in the country. The fact that Japan had a proper early warning is maybe shown by the low rate of young-adult victims, as they were able to evacuate fast. In Samoa, the high female mortality rate for age groups over 19 years old has, however, a different explanation. It has probably more to do with gender roles related to the high birth rate and care of children. Regarding the higher male mortality in the 0-9 year old age group, it could be associated with a coincidence and the relatively small number of total child victims (68) compared to other events, as there are no relevant physical differences between boys and girls of that age. The higher male mortality in Chile is mainly related to children and the elderly. The male to female mortality ratio (in number of victims) is $18: 10,17: 14$ and $19: 14$ for people below 10 years old, above 60 years and above 70 years old, respectively. The small number of victims considered 
A.

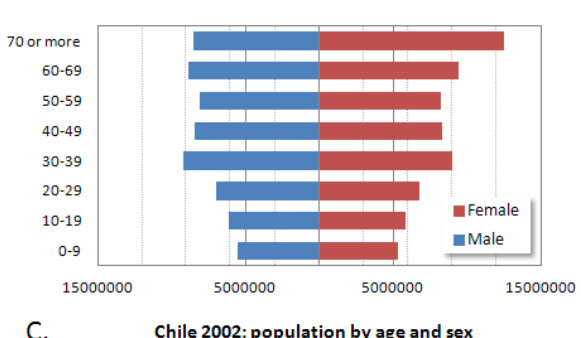

C.

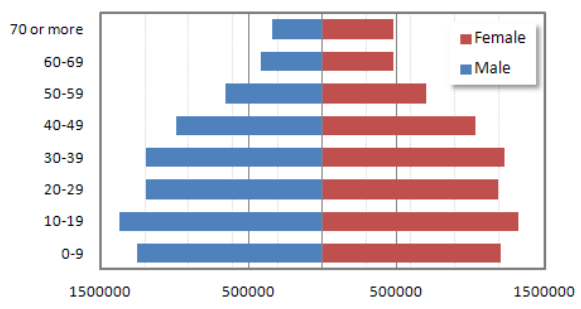

E. Samoa 2006: population by age and sex

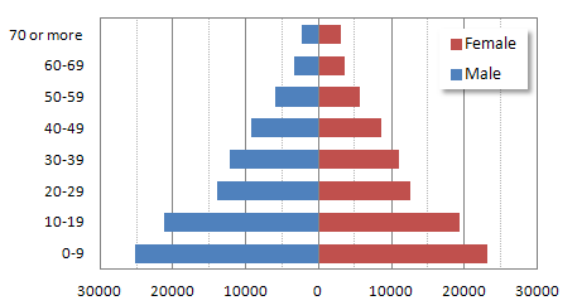

G. Sri Lanka 2001: population by age and sex

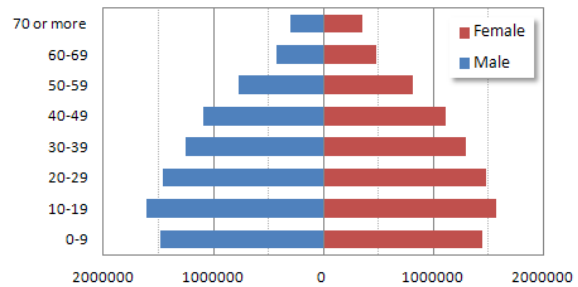

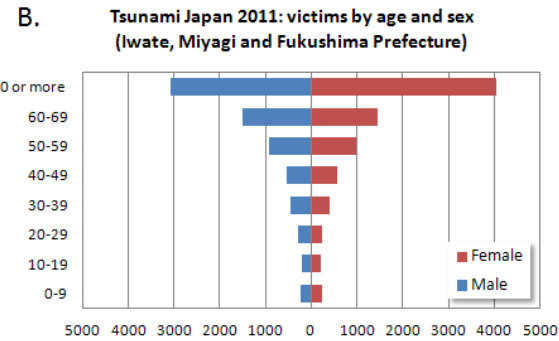

D. Tsunami Chile 2010: victims by age and sex

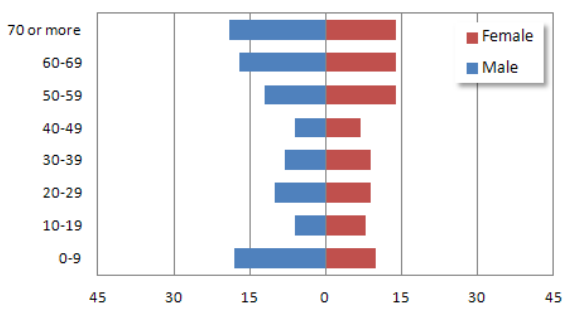

F. Tsunami Samoa 2009: victims by age and sex

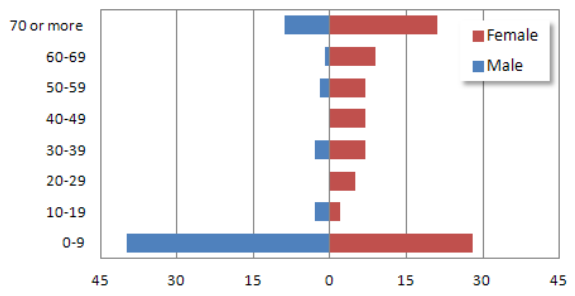

H. Tsunami Sri Lanka 2004: victims by age and sex

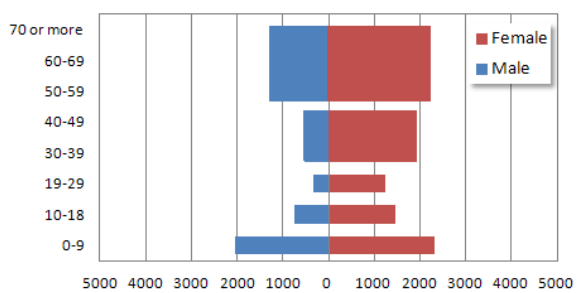

Figure 6. Population pyramids (tsunami events of Japan 2011, Chile 2010, Samoa 2009 and Sri Lanka 2004) according to: (a), (c), (e) and (g) pre-tsunami census data, and (b), (d), (f) and (h) data on tsunami victims. The age of tsunami victims over 30 years old in Sri Lanka is not available disaggregated in ranges of 10 years $(\mathbf{h})$.
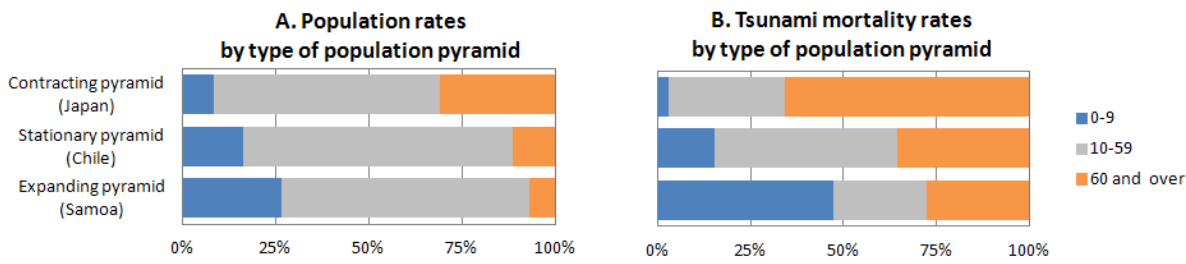

Figure 7. Comparison between (a) population rates and (b) tsunami mortality rates by age and type of population pyramid (tsunami events of Japan 2011, Chile 2010 and Samoa 2009).

cannot statistically back up a conclusion on male mortality or male vulnerability. In Sri Lanka, the high female mortality rate for all the age groups may be related to three aspects, the first two being closely linked: the timing of the tsunami, the gender-related cultural issues and the disability of the population. 

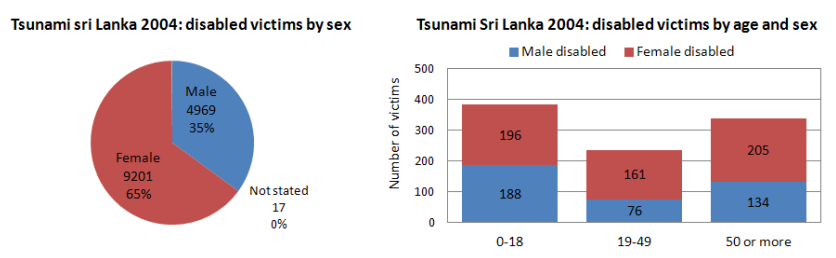

Figure 8. Tsunami disabled victims by age and sex (Sri Lanka tsunami 2004).

\subsubsection{Disability}

Disability, understood as any physical and/or mental limitation affecting the mobility of people and/or the ability to understand a warning message respectively, is referred by several authors (UNU-EHS, 2009; Dwyer et al., 2004; González-Riancho et al., 2014; Grezio et al., 2012; Post et al., 2009) to be a critical factor hindering evacuation. This indicator is analysed and validated here through the tsunami impacts in Sri Lanka in 2004, as no data are available for the other events.

As mentioned before, the 2004 Indian Ocean tsunami hit rural communities on Sunday morning, when children and women were at home or at the beach but men were working away from home (i.e. tsunami timing and gender issues). Additionally, the analysis of the Sri Lankan disabled victims by sex and age (Fig. 8) shows a higher percentage of female disabled victims $(65 \%)$ than male, while the census 2001 shows a male to female disability ratio of $1.3: 1$. Analysing the disabled victims by age group, the percentage of female disability for the $0-18,19-49$ and 50 or older age groups is 51,68 and $60 \%$ respectively. These disability conditions might have contributed to the higher mortality in women.

The 2001 census states that $2 \%$ of the Sri Lankan population were disabled, of which $3 \%$ were affected by mental limitations, while $97 \%$ were affected by different physical limitations: $18 \%$ in seeing, $19 \%$ in hearing/speaking, $24 \%$ in hands, $12 \%$ in legs and $24 \%$ other physical disability. These percentages imply that disability in Sri Lanka is associated with understanding a warning message in $22 \%$ (total mental and hearing/speaking limitations) of cases and to mobility and evacuation speed in $88 \%$ of cases. The 2004 post-tsunami census provided a $7 \%$ of disabled victims (another $7 \%$ of the victims had "not stated" disability), of which $30 \%$ corresponds to Mullaitivu, $21 \%$ to Ampara, $17 \%$ to Galle and $13 \%$ to Jaffna, as shown in Fig. 9. The number and distribution of disabled victims is related to the number of victims, not to the disabled population in 2001. In other words, higher numbers of disabled people do not translate into higher numbers of victims.

\subsubsection{Dependency}

Gender-related roles are highly connected to the concept of dependency in the field of disasters, as women, in many cases

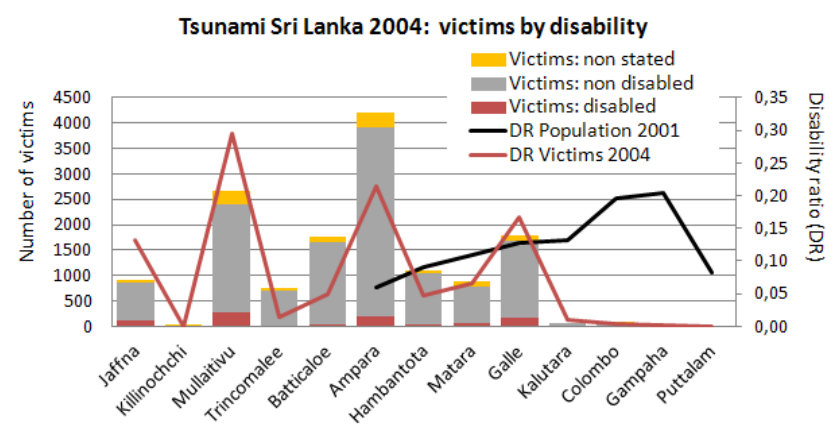

Figure 9. Tsunami victims in Sri Lanka (2004) by disability and pre-/post-tsunami disability ratios (disability ratio= disabled by district/total disabled). No data about disabled population in the Tamil districts (Jaffna-Batticaloe) are available in the 2001 census.

and countries, are in charge of caring after the family members at home, such as children, the elderly, ill and disabled people (Saito, 2012; Villagrán de León, 2008; Guha-Sapir et al., 2006; Birkmann, 2006; Oxfam, 2005; etc.). The dependency ratio has been calculated for the four countries as the added population below 10 and above 60 years old (dependent population), multiplied by 100 and divided by the population between 10 and 59 years old (active population). The dependency ratio has been found to be very high for Japan (65.22) and Samoa (50.77) due to the number of the elderly and children, respectively, and lower for both Chile (38.22) and Sri Lanka (38.09).

Considering these dependency ratios, to understand the number of victims strictly related to dependency issues, Fig. 10 presents the female mortality first considering all age groups (Fig. 10a) and then only the active female population that might be in charge of taking care of family members (Fig. 10b). The pre-tsunami census data (in a light red colour) show in both graphs a homogeneous male/female distribution of around $50 \%$ for all the countries and both analysed age groups. When analysing the female victims (in a dark red colour) for all age groups, higher mortality rates are found for Japan, Samoa and Sri Lanka. However, focusing on the female active population graph (Fig. 10b), only Samoa's and Sri Lanka's female mortality have been proved to be related to dependency issues; higher mortality in Japan $(53 \%)$, shown in Fig. 10a, is only associated with elderly female adults, due to a larger female longevity. Dependency and gender-related roles seem to be associated, to a greater extent, with undeveloped and developing countries. According to Ting and Woo (2009), traditionally, elderly care has been the responsibility of family members and was provided within the extended family home. Increasingly in modern societies, elderly care is now being provided by state or charitable institutions. The reasons for this change include decreasing family size, the greater life expectancy of elderly people, the geographical dispersion of families and the tendency for women to be educated and work outside the home. 

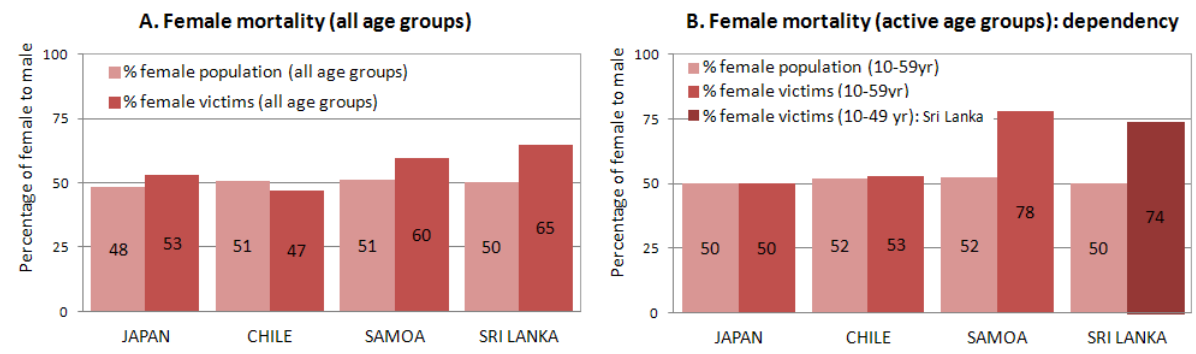

Figure 10. Female mortality for different tsunami events and its relationship with the concept of dependency (tsunami events of Japan 2011, Chile 2012, Samoa 2009 and Sri Lanka 2004). Pre-tsunami censuses appear in light red and tsunami victims in dark red. Panel (a) shows female mortality considering all age groups and panel (b) shows female mortality considering only the active age groups (10-59 years old for Japan, Chile and Samoa, while 10-49 years old for Sri Lanka due to data availability), assuming that women in this age range may have been in charge of family members (children and the elderly). Higher percentages of female victims in the active age group compared to the pre-tsunami percentages provide the female mortality associated with dependency issues.

The population in Japan has the highest life expectancy in the world and is ageing faster than any other industrialized country. Thus despite the laws designed to help ensure family support, traditional support that was once guaranteed is no longer assured today (Rickles-Jordan, 2007).

The Survey on Tsunami Evacuation, targeted at people affected by the earthquake and tsunami in the Iwate, Miyagi and Fukushima Japanese prefectures $(n=521$ women, 336 men), and jointly conducted by The Cabinet Office, Fire and Disaster Management Agency and the Japan Meteorological Agency in July 2011, concluded that almost $30 \%$ of males evacuated alone; women had a stronger connection with their local community than men, as $82 \%$ evacuated in small groups.

\subsection{Safety of buildings}

The safety of buildings, in terms of their capacity for providing shelter in case of a tsunami event, is analysed here as a human vulnerability indicator through the relationship between the number of victims and the type of damage to buildings for the different tsunami events, this information being available in the various tsunami censuses analysed. According to this relationship, several indicators affecting the type of damage (see Table 3) are analysed and validated in this section: type of building, shoreline distance and building materials.

The existing connection between the total number of victims and the number of buildings affected is shown in Fig. 11 for the tsunami events of Japan 2011, Sri Lanka and Thailand 2004. The Pearson correlation coefficient $(r)$ between the number of victims and total number of buildings affected is medium-high for the three events analysed, i.e. where $r$ is 0.53 (Japan), $r$ is 0.79 (Sri Lanka) and $r$ is 0.99 (Thailand). Moreover, the analysis of the type of damage in the affected buildings shows a very high correlation between the number of completely damaged buildings (total collapse category for Japan) and the number of victims: $0.88,0.86$ and 0.99 for
Japan, Sri Lanka and Thailand, respectively. In the cases of the Iwate prefecture in Japan, or Mullaitivu and Hambatota districts in Sri Lanka, a higher proportion of victims than affected buildings is identified, maybe due to the fact that a very high percentage of the affected buildings were completely damaged $(64 \%$ in Iwate, $91 \%$ Mullaitivu, $60 \%$ in Hambatota) so the population had almost no place for evacuation or shelter. Considering the completely damaged and partially damaged (unusable) houses as those that did not provide shelter during the tsunami event and that forced the population to escape and search for other shelters, there is a high correlation between these groups of buildings and mortality results.

The following analyses try to understand the possible correlation patterns between the building's type of damage and other variables such as distance to the sea, topography, type of building, water depth, building materials or number of storeys. Most of the data used come from the post-tsunami census of Sri Lanka 2004, together with some conclusions from previous publications regarding relevant aspects about the safety of buildings.

\subsubsection{Distance to the sea}

Figure 12 shows the analysis of the type of damage to buildings for the tsunami event in Sri Lanka in 2004 based on their distance to the sea. No data are available to analyse other events. There is a high correlation between distance to the sea and type of damage to buildings (Fig. 12b): $72 \%$ of the housing units within or on the $200 \mathrm{~m}$ boundary line from the shoreline were inoperative both as flooding shelter during the event and as housing units after the event, since they were completely damaged (62\%) or partially damagedunusable $(10 \%)$. The percentage of usable housing units after the event increases from $28 \%$ within or on the boundary line (Fig. 12b) to the $57 \%$ outside the boundary line (Fig. 12c). The distance to the sea is proved to be an important determining factor regarding the type of damage in 


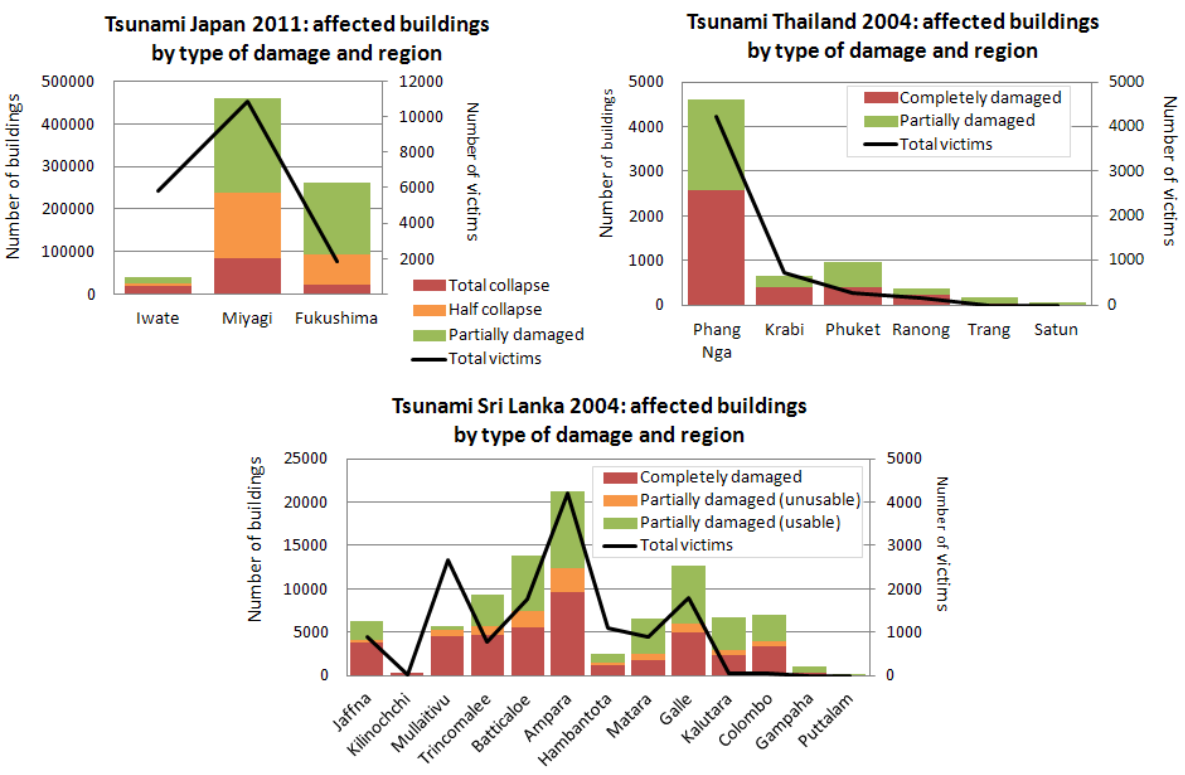

Figure 11. Correlation between total tsunami victims and affected buildings by type of damage and region (tsunami events of Japan 2011, Thailand 2004 and Sri Lanka 2004).

buildings and consequently the number of victims. This factor should be considered in future human vulnerability analyses.

\subsubsection{Coastal topography}

As far as coastal topography is concerned, Nakahara and Ichikawa (2013) suggested for Japan that the lower overall mortality rates in Fukushima may be due to the greater expanse of flatlands and the larger number of people living inland, and thus the smaller proportion of people inundated, in contrast to the situation in Iwate and Miyagi, where most of the population live in narrow coastal strips. Suppasri et al. (2013) proved that the damage probabilities for buildings located on the ria coast (2011 Tohoku tsunami, Ishinomaki city results) generally increase more and are higher than those in the plain coast, possibly due to higher velocities associated with the coastal topography. The probability of having buildings (mixed structural material) washed away for different inundation depths and for the plain coast and ria coast, respectively, is as follows: $<0.05$ and $0.4(2 \mathrm{~m})$, 0.1 and $0.6(3 \mathrm{~m}), 0.5$ and $0.8(5 \mathrm{~m})$ and 1 and $0.9(9 \mathrm{~m})$. Regarding the impacts of the 2004 Indian Ocean tsunami in Sri Lanka, Wijetunge (2014) stated that shore-connected waterways such as rivers, canals and other water bodies like lakes and lagoons provided a low-resistant path for the tsunami-induced surge to travel upstream into areas further interior in the study zone (southwest coast). Also, he compared the impacts on three adjacent coastal stretches (in Hikkaduwa Divisional Secretariat) to understand how different factors besides the oncoming tsunami amplitude explain the differences in the extent of inundation. Relatively low- lying onshore terrain, negative landward slopes and, probably to a lesser extent, the type and density of land cover are the main factors that have converged unfavourably to cause greater tsunami impact on one stretch (average inundation distance $1.2 \mathrm{~km}$ inland, 81 victims) compared to neighbouring stretches (average inundation distance 150 and $350 \mathrm{~m}$ inland, 12 and 19 victims, respectively).

The direct exposure of the Sri Lankan northern and eastern provinces (Jaffna-Ampara) to the tsunami trajectory, the location of the coastal communities on a flat coastal plain indented every few kilometres by coastal lagoons and local topography-related tsunami effects contributed to the huge death tolls in the area ( $72 \%$ of the victims).

\subsubsection{Type of building}

Figure 13a compares the number and percentage of buildings affected by the tsunami in Sri Lanka 2004 by type of building (housing and non-housing units) and type of damage together with the number of victims. Housing units (HU) are defined by the Sri Lankan Department of Census and Statistics (DCS) as those buildings which are places of dwelling of human beings, are separated from other places of dwelling and have a separate entrance, whether permanent or temporary structures such as huts, shanties, sheds, etc. Non-housing units (NHU) are those buildings or parts of a building which are not used as a place of dwelling, such as offices, petrol filling stations, shops, etc. Very similar percentages of type of damage have been obtained for the two types of buildings; nonetheless the total numbers are very different. From the total number of buildings affected ( 99546 buildings), $89 \%$ are HU (88 544 buildings) while $11 \%$ are NHU (11 002 build- 
A.

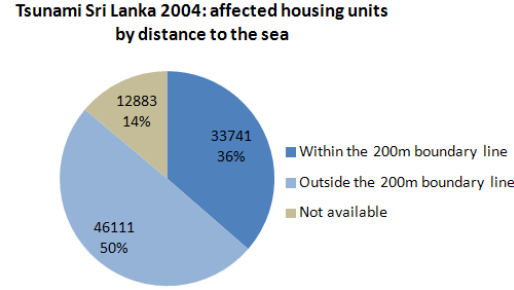

B.

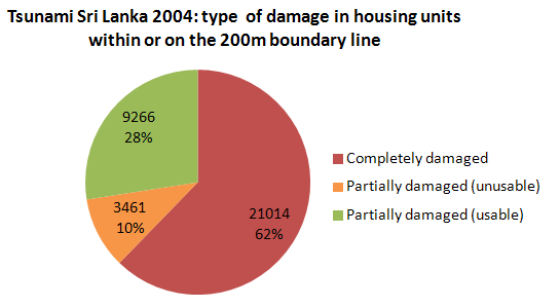

C.

Tsunami Sri Lanka 2004: type of damage in housing units outside the $200 \mathrm{~m}$ boundary line

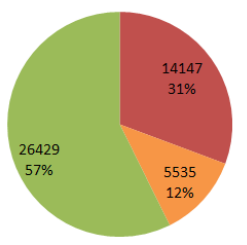

- Completely damaged

w- Partially damaged (unusable) $n$ Partially damaged (usable)
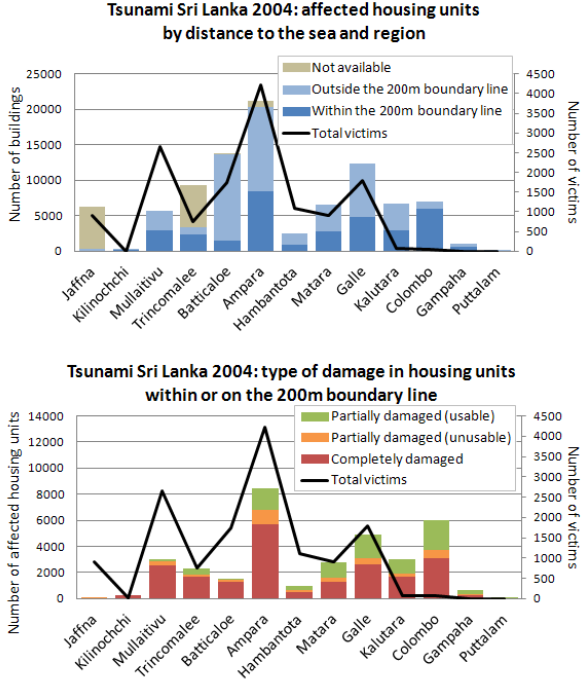

Tsunami Sri Lanka 2004: type of damage in housing units outside the $200 \mathrm{~m}$ boundary line

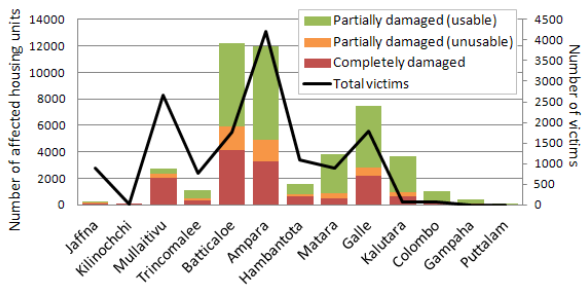

Figure 12. Correlation between number of tsunami victims, buildings' type of damage and distance to the sea (Sri Lanka tsunami 2004).
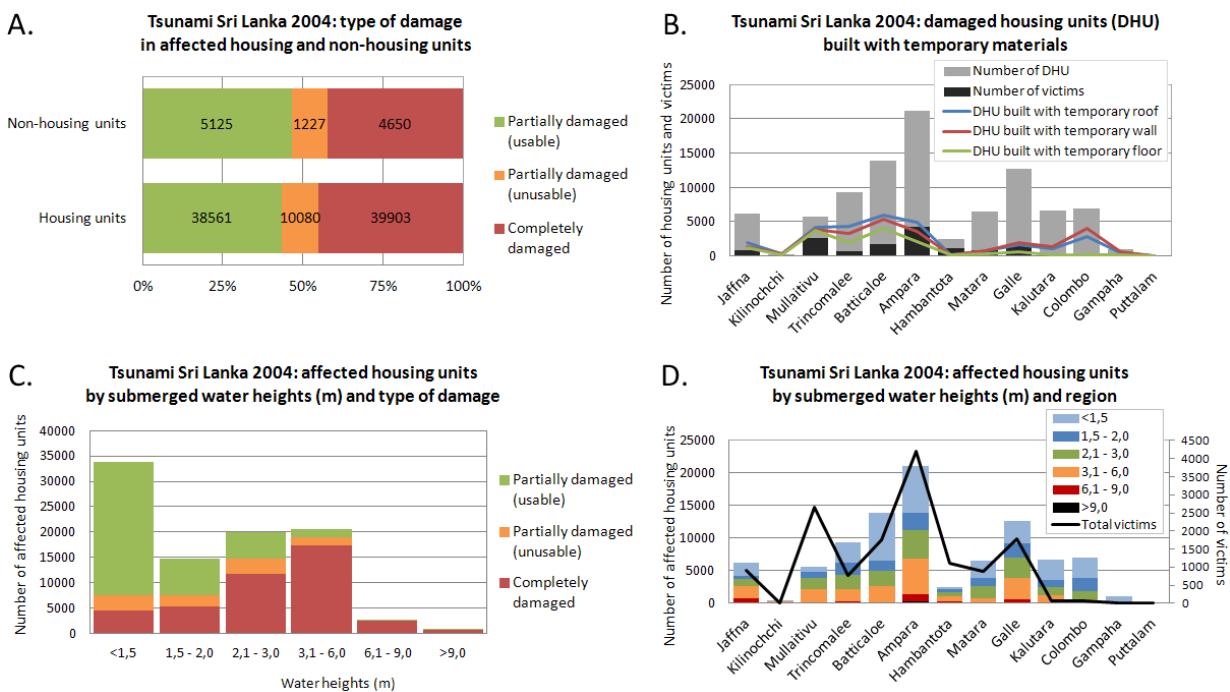

Figure 13. Analysis of damaged buildings (Sri Lanka tsunami 2004) according to (a) comparison between number of housing units (HU) and non-housing units (NHU) affected by type of damage; (b) correlation between numbers of tsunami victims, damaged HU and building materials and (c) and (d) correlation between numbers of tsunami victims, buildings' type of damage and water depths.

ings). The tsunami census carried out by the Sri Lankan government focuses on HU; therefore, the next analyses in Fig. 13 do so as well.

\subsubsection{Building materials and water depths}

Figure 13b shows the damage to Sri Lankan HUs by type of material. The affected buildings in the area from Jaffna 
to Ampara show higher percentages of temporary materials and have associated higher numbers of victims. Mullaitivu had 5700 affected HUs (ninth position among the 13 districts) with 2652 victims representing $19 \%$ of the total victims (second district most affected). This huge human impact can partly be explained by the building materials, as $72 \%$ of the damaged HUs had temporary roofs, $68 \%$ had temporary walls and $65 \%$ had temporary floors; these were the highest percentages among the 13 districts. This result highlights the relevance of materials in the response of buildings to the impacts of the tsunami. This is coherent with the result obtained in Fig. 11, where Mullaitivu appears with $77 \%$ of affected buildings as completely damaged.

Figure $13 \mathrm{c}$ shows the correlation between type of damage to HUs and water depths. Almost $73 \%$ of the HUs affected by water heights between 2.1 and $3 \mathrm{~m}$ in Sri Lanka were critically damaged (completely and partially-unusable), the percentage increasing up to 92 and $94 \%$ for water heights above 3.1 and $6.1 \mathrm{~m}$, respectively. Fig. 13d shows the correlation between the number of affected HUs with submerged water heights and the number of victims by region. Based on the affected HUs, Jaffna, Ampara and Galle received the highest tsunami waves, with between 101 and 350 HUs having faced waves of more than $9 \mathrm{~m}$.

According to the fragility functions developed for Samoa 2009 by Reese et al. (2011), severe damage and collapse are clearly a result of building type, with residential timber structures the most fragile, followed by masonry residential and reinforced concrete residential structures. Based on residential masonry building data, it was clearly shown that shielding reduces, while entrained debris increases, the fragility of structures (i.e. reduces the damage state exceedance probability for a given water depth). These results roughly confirm the observations made in the aftermath of the 2004 Indian Ocean tsunami in Banda Aceh (Leone et al., 2011) and of the 2006 Java tsunami where exposed buildings had sustained damage levels 2 to 5 times higher than the shielded ones (Reese et al., 2007). The tsunami fragility curves provided by Suppasri et al. (2013) for Japan 2011, showed that reinforced concrete $(\mathrm{RC})$ is the strongest structure against water depth, followed by steel, masonry and wood. All wood buildings and most lightweight buildings were washed away when inundation depth was $>10 \mathrm{~m}$ while only $50 \%$ or fewer steel and RC buildings were washed away; these latter materials played therefore a very important role in preventing a building from collapsing or being washed away. The tsunami fragility curves provided by Tinti et al. (2011) for Banda Aceh (Indonesia) 2004 also prove that the damage increases with flow depth for all building materials. Total collapse of buildings occurs to light constructions and reinforced concrete buildings with flow depths of about $4 \mathrm{~m}$ and more than $15 \mathrm{~m}$, respectively.

\subsubsection{Number of storeys}

According to Suppasri et al. (2013) for the 2011 Tohoku tsunami, buildings of three or more storeys were confirmed to be much stronger than the buildings of one or two storeys under the same inundation depth (results provided for reinforced concrete and wood buildings). The differences in damage probability between one-storey and two-storey buildings were not very large. However, the damage probability is significantly reduced for the case of multi-storey buildings over three floors; the probability of having a RC building washed away was 0.2 for a $10 \mathrm{~m}$ inundation depth. According to the UNESCO ITST Samoa (2009), buildings are more likely to survive with less damage if they have elevated floor levels, reinforced concrete or core-filled concrete block walls, sound foundations, are shielded and are well constructed.

To sum up the results on safety of buildings, the number of victims is directly related to the number and type of damage to affected buildings, being highly correlated to the number of completely damaged ones. The type of damage depends on the location of the building and the building fragility. The location of the building implies higher or lesser flow depths conditioned by the distance to the sea and the topography, while the building fragility relates to the resistance of the building to the hazard and depends on the building materials and the number of storeys. Therefore, it is proposed here to include these two building-related aspects (location and fragility) in future human vulnerability assessments.

\subsection{Economic resources}

Population groups with lower incomes are more sensitive to the threat due to various reasons, related to living in precarious areas, having homes built with non-resistant materials and most likely not having property insured, having less money to recover from the impact (e.g. rebuilding a home, surviving unemployed for a while, economically supporting the family, migrating).

According to this idea, the indicators from Table 3 that could be validated in this section are income/savings/poverty and employment/type of occupation. However, unlike the other events, only the Sri Lanka 2004 post-tsunami census characterizes the victims based on such criteria. These socioeconomic indicators are usually proposed and applied in tsunami vulnerability assessments as an insight on the potential recovery capacity of the exposed communities, based on the household economic resources or the expected impacts affecting recovery (key issues VIII and X, respectively; see Table 1). Nevertheless, when working with the actual fatalities associated with different monthly income or with each type of occupation or livelihood, the information obtained is very different. This difference relates to whether to count actual or potential losses in the assessment. The acquired knowledge based on post-tsunami data focuses on 

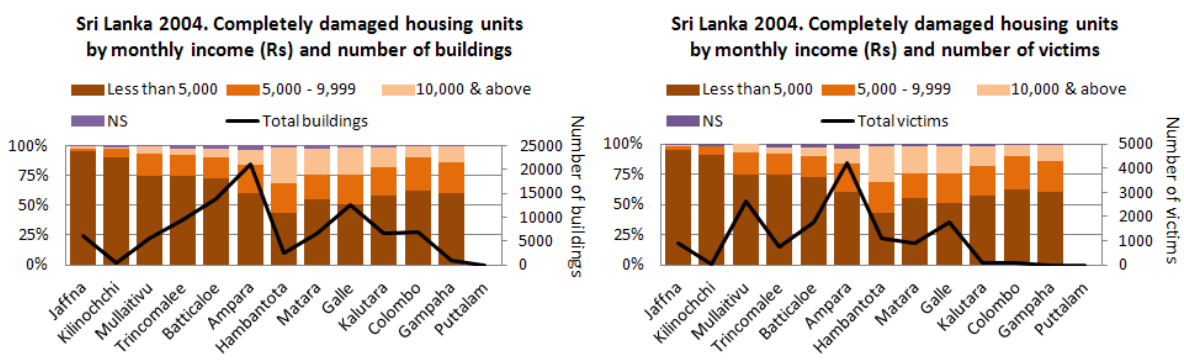

Figure 14. Percentage distribution of completely damaged housing units (left) and number of tsunami victims (right) by reported monthly income of the housing unit (Sri Lanka tsunami 2004). LKR 5000= EUR 27.71, on 10 July 2014.

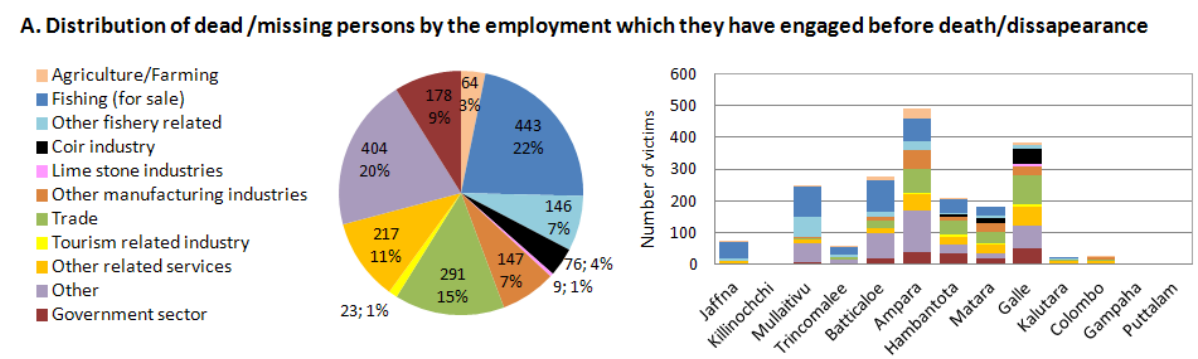

B. Distribution of dead /missing persons by employment and sex

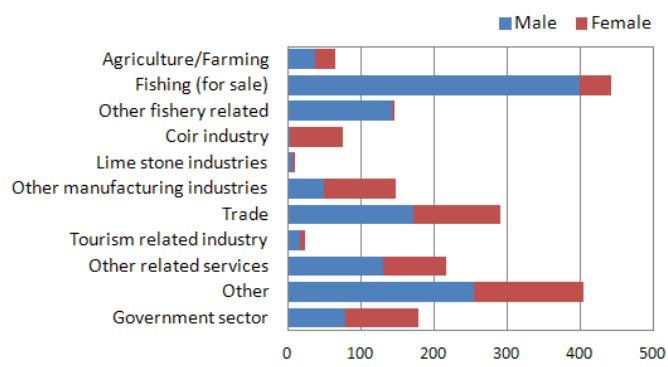

Figure 15. Distribution of tsunami victims by employment and district (Sri Lanka tsunami 2004). Panel (a) shows distribution of dead/missing persons by the employment they were engaged in before death/disappearance; panel (b) shows distribution of dead/missing persons by employment and sex.

the understanding of (i) poverty-related human vulnerability, (ii) which the most vulnerable livelihoods are in terms of activity location, cultural traditions, the different gender roles by activity, etc.; (iii) which livelihoods struggle after the event due to lack of workers; and (iv) which livelihoods will suffer economic losses with the subsequent impact to households' and country's economies.

Figure 14 shows the number of victims and affected buildings and the percentage distribution of completely damaged HUs, by reported monthly income of the HU. Very high percentages of low-income profile HUs are found for this type of damage, especially in the northern and eastern provinces (Jaffna-Batticaloe), where 73-95\% of the completely damaged HUs had a monthly income of less than LKR 5000 (EUR 27.71, on 10 July 2014). The percentage of HU within this income category is around $50-60 \%$ in the other districts.

Figure 15a shows that $32 \%$ of the victims in Sri Lanka were related to the primary sector of the economy (3\% agri- culture/farming, $29 \%$ fishing), $12 \%$ to the secondary sector $(4 \%$ coir industry, $1 \%$ lime stone industry and $7 \%$ other manufacturing industries), $27 \%$ to the tertiary sector $(15 \%$ trade, $1 \%$ tourism and $11 \%$ other related services), $9 \%$ to the government sector and $20 \%$ to an unidentified category ("other"). The victims from the northern and eastern provinces (Jaffna-Batticaloe) are mainly related to fishing, while from Ampara to Galle (southern province) the victims are more related to the government sector, tourism, trade and services, coir and other manufacturing industries.

Figure $15 \mathrm{~b}$ shows the distribution of victims by employment and sex. $65 \%$ of the victims with identified employment $(n=1998)$ were men; this higher percentage relates to the higher female unemployment rate (13.0) than for males (7.9), according to the 2001 Sri Lankan Census. This figure allows for the understanding of cultural gender roles related to livelihoods. Fishery activity, for example, is mainly male (90-97\% male victims) while the coir industry instead is a 
Table 5. Summary of the conclusions obtained on tsunami vulnerability indicators (where DRR is the death rate ratio, HU is the housing unit and NHU is the non-housing unit).

\begin{tabular}{ll}
\hline Conclusions on vulnerability indicators & Validated in \\
\hline \multicolumn{1}{c}{ Human exposure } & \\
\hline $\begin{array}{l}\text { Exposure: human exposure is not only related to population density. Important to consider indicators related } \\
\text { to buildings as well as temporal exposure patterns related to livelihoods, cultural traditions and gender roles. }\end{array}$ & $\begin{array}{l}\text { Japan, Chile, } \\
\text { Hazard modelling essential to identify exposed area and wave depths. }\end{array}$ \\
\hline \multicolumn{1}{c}{ Mobility and evacuation speed } & Japan, Chile, Samoa, \\
\hline $\begin{array}{l}\text { Age: the elderly and children are vulnerable age groups, the former having higher mortality rates. Mortality } \\
\text { of other age groups just related to the population structure before an event. Child age groups (0-4 and }\end{array}$ & Sri Lanka \\
$\begin{array}{l}\text { 5-9 years) equally vulnerable in high death toll events. DRR conditioned by country's development profile } \\
\text { (population pyramids), being especially high for age groups above 60 years old and increasing with age. }\end{array}$ & \\
\hline $\begin{array}{l}\text { Sex/gender: female mortality is not always higher. Further considerations needed (population pyramids, } \\
\text { development profile of the country, longevity, gender roles, dependency, cultural traditions etc.). }\end{array}$ & Japan, Chile, Samoa, \\
\hline $\begin{array}{l}\text { Disability: the number and distribution of disabled victims is related to the number of victims, not to the disabled } \\
\text { population in the pre-tsunami census. Higher numbers of disabled people do not translate into higher numbers of } \\
\text { victims. }\end{array}$ & Sri Lanka \\
\hline $\begin{array}{l}\text { Dependency: female mortality is not always related to dependency issues (only Samoa and Sri Lanka in this work). } \\
\begin{array}{l}\text { Dependency and gender-related roles seem to be associated, to a greater extent, with undeveloped and developing } \\
\text { countries. }\end{array}\end{array}$ & $\begin{array}{l}\text { Japan, Chile, Samoa, } \\
\text { Sri Lanka }\end{array}$ \\
\hline
\end{tabular}

\begin{tabular}{|c|c|c|}
\hline \multicolumn{3}{|c|}{ Safety of buildings } \\
\hline \multicolumn{2}{|r|}{$\begin{array}{l}\text { Type of damage: high correlation between affected buildings and number of victims, very high for completely } \\
\text { damaged buildings. }\end{array}$} & $\begin{array}{l}\text { Japan, Samoa, } \\
\text { Sri Lanka }\end{array}$ \\
\hline \multirow[t]{3}{*}{$\begin{array}{l}\text { Building } \\
\text { location }\end{array}$} & $\begin{array}{l}\text { Distance to the sea: distance to the sea is proved to be an important determining factor regarding } \\
\text { the type of damage in buildings and consequently the number of victims. } 72 \% \text { of the housing units } \\
\text { within the } 200 \mathrm{~m} \text { boundary line from the shoreline were completely damaged. }\end{array}$ & Sri Lanka \\
\hline & $\begin{array}{l}\text { Coastal topography: higher mortality rates in narrow coastal strips compared to flatlands. Higher } \\
\text { probability of buildings damage in ria coast compared to plain coast. Greater tsunami impacts on } \\
\text { shore-connected waterways, low-lying onshore terrain and negative landward slopes. }\end{array}$ & $\begin{array}{l}\text { Japan (Nakahara and } \\
\text { Ichikawa, 2013; } \\
\text { Suppasri et al., 2013) } \\
\text { Sri Lanka } \\
\text { (Wijetunge, 2013) }\end{array}$ \\
\hline & Shielding: shielding reduces the fragility of structures. & $\begin{array}{l}\text { Samoa (Reese et al., } \\
\text { 2011), Java (Reese et } \\
\text { al., 2007), Sumatra } \\
\text { (Leone et al., 2011) }\end{array}$ \\
\hline \multirow{5}{*}{$\begin{array}{l}\text { Building } \\
\text { fragility }\end{array}$} & Type of building: not relevant. HU and NHU had similar percentages of type of damage. & Sri Lanka \\
\hline & $\begin{array}{l}\text { Building materials: high correlation between building materials, type of damage and number } \\
\text { of victims. Affected buildings present higher percentages of temporary materials and have higher } \\
\text { associated numbers of victims. }\end{array}$ & Sri Lanka \\
\hline & $\begin{array}{l}\text { Water depths: high correlation between water depths, building materials and type of damage. } \\
\text { Almost } 73 \% \text { of HUs affected by water heights between } 2.1 \text { and } 3 \mathrm{~m} \text { in Sri Lanka were critically } \\
\text { damaged. Higher percentages of lightweight buildings washed away compared to reinforced } \\
\text { buildings under the same inundation depth in Indonesia and Japan. }\end{array}$ & $\begin{array}{l}\text { Sri Lanka; Indonesia } \\
\text { (Tinti et al., 2011), } \\
\text { Japan (Suppasri et al., } \\
\text { 2013) }\end{array}$ \\
\hline & Debris: entrained debris increases the fragility of structures. & $\begin{array}{l}\text { Samoa (Reese et al., } \\
\text { 2011) }\end{array}$ \\
\hline & $\begin{array}{l}\text { Storeys: buildings of three or more storeys confirmed to be much stronger than buildings of one } \\
\text { or two storeys under the same inundation depth. }\end{array}$ & $\begin{array}{l}\text { Japan (Suppasri et al., } \\
\text { 2013) }\end{array}$ \\
\hline \multicolumn{3}{|c|}{ Economic resources } \\
\hline \multicolumn{2}{|r|}{$\begin{array}{l}\text { Income/poverty: very high percentages of low-income-profile related to completely damaged housing units. } \\
\text { Vulnerable groups and impacts affecting recovery. }\end{array}$} & Sri Lanka \\
\hline \multicolumn{2}{|c|}{$\begin{array}{l}\text { Type of occupation: the activity location (tsunami exposure), its social and economic contribution as well } \\
\text { as gender-related aspects are important to identify vulnerable livelihoods and potential socioeconomic } \\
\text { impacts affecting recovery. }\end{array}$} & Sri Lanka \\
\hline
\end{tabular}


female activity ( $96 \%$ female victims). To assess the vulnerability of the socioeconomic activities of a study site it is important to acknowledge the location where each activity takes place in terms of tsunami exposure, its social and economic contribution to the community, region or country, as well as gender-related aspects. This will facilitate the promotion of adequate awareness and training campaigns on the various risk reduction measures.

\subsection{Summary of major findings}

Table 5 summarizes the main results obtained from the analyses presented in this work.

\section{Conclusions}

After several tsunami events with disastrous consequences around the world, coastal countries have realized the need to be prepared, which is conditioned by the existence of early warning systems, the development of tsunami risk assessments to identify critical spots and various awareness and training campaigns, among others. Consequently, the international scientific community is striving to develop and validate methodologies for tsunami hazard, vulnerability and risk assessments.

A comprehensive review of the existing works on tsunami vulnerability assessment based on indicators has been carried out to identify those currently used to assess human vulnerability. Most authors agree on some indicators such as age, sex, illiteracy, disability, critical buildings, number of floors etc., and some of them add some more creativity, trying to capture all aspects affecting in some way the preparedness and response to such event, e.g. coordination networks, social awareness, and so on. Although the various authors propose and apply different indicators according to the scope of their work and the available information, all of the applied exposure and vulnerability indicators follow specific thematic areas and have been organized within four main categories and 10 key issues.

To validate the compiled indicators, the impacts generated in several countries (Japan, Chile, Samoa, Sri Lanka and Thailand) by the 2011 Great Tohoku tsunami, the 2010 Chilean tsunami, the 2009 Samoan tsunami and the 2004 Indian Ocean tsunami are evaluated. The validation is based on the comparison of the pre- and post-tsunami official censuses to understand if the tsunami mortality trends are related to the event itself or to pre-tsunami existing population patterns and vulnerability characteristics. This section demonstrates the most relevant results.

Permanent human exposure, understood as the number of communities/people normally located in the hazard area, is proved to not only be related to population density of the administrative unit (which is the most commonly applied indicator) but also related to the exposed area. Tsunami hazard modelling is essential to identify the communities at risk. Temporal human exposure is related to sitespecific livelihoods, cultural traditions and gender roles, has daily/weekly/monthly variability and requires studying the temporal patterns of the community before proposing vulnerability indicators. This is the case, for example, for the tsunami impacts in Sri Lanka on Sunday morning, where women and children were at the beach while men were fishing.

Focusing on the population-based indicators, age has proved to be important in a vulnerability assessment. Death rate ratios (DRR) by age groups are provided in this work to understand whether the death related to each age group is associated with a higher vulnerability to the tsunami event or to the pre-event structure of the population. The DRR are conditioned by the country's development profile (population pyramids). The results confirm that the most vulnerable age groups are the elderly and children; however the former have much higher mortality rates than children; the rates are especially high for age groups above 60 years old and increase with age. Mortality of other age groups is just related to the population structure before an event. Child age groups ( 0 4 and 5-9 years) are equally vulnerable in high death toll events. Regarding sex/gender issues, it has been found that female mortality is not always higher than male mortality. Consequently, further considerations are needed regarding the development profile of the country and associated population pyramid, potential women longevity, gender roles, dependency, cultural traditions, etc. Also, female mortality is not always related to dependency issues (only in Samoa and Sri Lanka in this work). Dependency and gender-related roles seem to be an issue to a greater extent in undeveloped and developing countries. Regarding disability, higher numbers of disabled people did not translate into higher numbers of victims in the affected districts of Sri Lanka.

Furthermore, based on the overall results obtained, it is clear that mortality is not only related to the characteristics of the population but also to the buildings. In this sense, a high correlation has been found between the affected buildings and the number of victims, being very high for completely damaged buildings. The factors determining the type of damage in buildings have been analysed and can be grouped into two categories: building location and building fragility. Regarding the building location, the distance to the sea has proved to be an important determining factor; it is consequently correlated to the number of victims. Regarding the building fragility, building materials and expected water depths have been confirmed to be high correlated to the type of damage, which agrees and reinforces previous works on the topic in different countries (Tinti et al., 2011; Suppasri et al., 2013). The calculation of tsunami water depths requires numerical modelling of the hazard.

As highlighted in this section, tsunami hazard modelling is essential to identify the exposed area and communities, as 
well as the expected wave depths; both indicators condition the expected number of victims.

The results and conclusions presented in this paper validate, in light of past tsunami events, some of the indicators currently proposed by the scientific community to measure human vulnerability and help define site-specific indicators for future tsunami vulnerability assessments.

Finally, we would like to highlight the excellent work done by the government of Sri Lanka in characterizing the impacts suffered as a result of the Indian Ocean tsunami of 2004 and the great usefulness to science of making this information available and easily accessible to the public.

Acknowledgements. The authors acknowledge the European Union 7th Framework Programme project ASTARTE (Assessment, Strategy And Risk Reduction for Tsunamis in Europe) in the framework of which this work was performed and funded.

Edited by: I. Didenkulova

Reviewed by: A. Armigliato and one anonymous referee

\section{References}

ADPC (Asian Disaster Preparedness Center): Thailand - Post Rapid Assessment Report: Dec 26th 2004 Tsunami, available at: http://www.adpc.net/v2007/ikm/ONLINEDOCUMENTS/ downloads/TsunamiRapidAssessmentReport_15Feb.pdf (last access: 1 August 2014), 2007.

Alliance Development Works in collaboration with United Nations University and The Nature Conservancy: World Risk Report 2012, Alliance Development Works, Berlin, ISBN 978-39814495-0-3, 2012.

Álvarez-Gómez, J. A., Aniel-Quiroga, Í., Gutiérrez-Gutiérrez, O. Q., Larreynaga, J., González, M., Castro, M., Gavidia, F., Aguirre-Ayerbe, I., González-Riancho, P., and Carreño, E.: Tsunami hazard assessment in El Salvador, Central America, from seismic sources through flooding numerical models., Nat. Hazards Earth Syst. Sci., 13, 2927-2939, doi:10.5194/nhess-132927-2013, 2013.

Arikawa, T., Tatsumi, D., Matsuzaki, Y., and Tomita, T.: Field Survey on 2009 Samoa Islands Tsunami, Technical Note of The Port and airport Research Institute PARI, No. 1211, 2010.

Birkmann, J.: Measuring the un-measurable, UNU-EHS SOURCE 5/2006, Bonn, Germany, 2006.

CRED (Centre for Research on the Epidemiology of Disasters): The human cost of natural disaster, a global perspective, available at: http://emdat.be/human_cost_natdis, last access: 15 May 2015.

Cruz, A. M., Krausmann, E., and Franchello, G.: Analysis of tsunami impact scenarios at an oil refinery, Nat. Hazards, 58, 141-162, doi:10.1007/s11069-010-9655-x, 2011.

Dall'Osso, F., Gonella, M., Gabbianelli, G., Withycombe, G., and Dominey-Howes, D.: Assessing the vulnerability of buildings to tsunami in Sydney, Nat. Hazards Earth Syst. Sci., 9, 2015-2026, doi:10.5194/nhess-9-2015-2009, 2009.

Damm, M.: Mapping Social-Ecological Vulnerability to Flooding, Graduate Research Series, PhD dissertations, Publication Series of UNU-EHS Vol. 3, United Nations University - Institute for Environment and Human Security (UNU-EHS), Bonn, ISBN: 978-3-939923-46-6, 2010.

Dengler, L., Araya, S., Graehl, N., Luna, F., and Nicolini, T.: Factors that exacerbated or reduced impacts of the 27 February 2010 Chile Tsunami, Earthq. Spectra, 28, S199-S213, 2012.

Department of Census and Statistics of Sri Lanka: Census of Population and Housing 2001, available at: http://www.statistics.gov. lk/PopHouSat/Pop_Chra.asp (last access: 11 July 2014), 2001.

Department of Census and Statistics of Sri Lanka: Census of Persons, Housing Units and Other Buildings affected by Tsunami, 26 December 2004, available at: http://www.statistics.gov.lk/ tsunami/ (last access: 11 July 2014), 2004.

Doocy, S., Rofi, A., Moodie, C., Spring, E., Bradley, S., Burnham, G., and Robinson, C.: Tsunami mortality in Aceh Province, Indonesia, B. World Health Organ., 85, 273-278, 2007.

Dwyer, A., Zoppou, C., Nielsen, O., Day, S., and Roberts, S.: Quantifying Social Vulnerability: A methodology for identifying those at risk to natural hazards, Geoscience Australia Record 2004/14, available at: http://www.ga.gov.au/image_ cache/GA4267.pdf (last access: 15 December 2014), 2004.

Eckert, S., Jelinek, R., Zeug, G., and Krausmann, E.: Remote sensing-based assessment of tsunami vulnerability and risk in Alexandria, Egypt, Appl. Geogr., 32, 714-723, 2012.

Fiscalía Nacional de Chile: Nómina de fallecidos por el tsunami del 27.02.10 (31 de enero de 2011), available at: http://www. fiscaliadechile.cl/Fiscalia/sala_prensa/noticias_det.do?id=125 (last access: 1 August 2014), 2010 (in Spanish).

Fritz, H. M., Petroff, C. M., Catalán, P., Cienfuegos, R., Winckler, P., Kalligeris, N., Weiss, R., Barrientos, S. E., Meneses, G., Valderas-Bermejo, C., Ebeling, C., Papadopoulos, A., Contreras, M., Almar, R., Dominguez, J. C., and Synolakis, C. E.: Field survey of the 27 February 2010 Chile Tsunami, Pure Appl. Geophys., 168, 1989-2010, 2011.

González-Riancho, P., Aguirre-Ayerbe, I., García-Aguilar, O., Medina, R., González, M., Aniel-Quiroga, I., Gutiérrez, O. Q., Álvarez-Gómez, J. A., Larreynaga, J., and Gavidia, F.: Integrated tsunami vulnerability and risk assessment: application to the coastal area of El Salvador, Nat. Hazards Earth Syst. Sci., 14, 1223-1244, doi:10.5194/nhess-14-1223-2014, 2014.

Goseberg, N. and Schlurmann, T.: Tsunami Hazard Mapping and Risk Assessment for the City Of Padang/West Sumatra, LastMile-Evacuation Project, Conference: Disaster Risk Reduction for Natural Hazards: Putting Research into Practice, London, available at: http://www.ucl.ac.uk/drrconference/presentations/ TSchlurmann.pdf (last access: 18 March 2014), 2009.

Government of Japan, Cabinet Office, Gender Equality $\mathrm{Bu}-$ reau: Disaster Prevention and Reconstruction from a Gender Equal Society Perspective - Lessons from the Great East Japan Earthquake, From the "White Paper on Gender Equality 2012”; available at: http://www.gender.go.jp/english_contents/ index.html (last access: 11 July 2014), 2012.

Government of Samoa: TSUNAMI, Samoa, 29 September 2009, available at: http://www.preventionweb.net/files/27077_ tsunamipublication2wfblanks.pdf (last access: 1 August 2014), 2010.

Greiving, S., Fleischhauer, M., and Lückenkötter, J.: A methodology for an integrated risk assessment of spa- 
tially relevant hazards, J. Environ. Plann. Man., 49, 1-19, doi:10.1080/09640560500372800, 2006.

Grezio, A., Gasparini, P., Marzocchi, W., Patera, A., and Tinti, S.: Tsunami risk assessments in Messina, Sicily - Italy, Nat. Hazards Earth Syst. Sci., 12, 151-163, doi:10.5194/nhess-12-151-2012, 2012

Guha-Sapir, D., Parry, L. V., Degomme, O., Joshi, P. C., and Saulina Arnold, J. P.: Risk factors for mortality and injury: post-tsunami epidemiological findings from Tamil Nadu. CRED, School of Public Health, Catholic University of Louvain, Brussels, Belgium, available at: http://www.em-dat.net/documents/ Publication/RiskFactorsMortalityInjury.pdf (last access: 15 May 2015), 2006.

Gupta, H. K. and Gahalaut, V. K.: Three Great Tsunamis: Lisbon (1755), Sumatra-Andaman (2004) and Japan (2011), Springer Dordrecht Heidelberg New York London, doi:10.1007/978-94007-6576-4, 2013.

Harbitz, C. B., Glimsdal, S., Bazin, S., Zamora, N., Løvholt, F., Bungum, H., Smebye, H., Gauera, P., and Kjekstad, O.: Tsunami hazard in the Caribbean: regional exposure derived from credible worst case scenarios, Cont. Shelf Res., 38, 1-23, doi:10.1016/j.csr.2012.02.006, 2012.

Igarashi, Y., Kong, L., Yamamoto, M., and McCreery, C. S.: Anatomy of historical Tsunamis: lessons learned for tsunami warning, Pure Appl. Geophys., 168, 2043-2063, 2011.

Instituto Nacional de Estadísticas de Chile: Censo 2002, Comisión Nacional del XVII Censo de Población y VI de Vivienda, available at: www.ine.cl/cd2002/sintesiscensal.pdf (last access: $1 \mathrm{Au}-$ gust 2014), 2003

Jonkman, S. N., Vrijling, J. K., and Vrouwenvelder, A. C. W. M.: Methods for the estimation of loss of life due to floods: a literature review and a proposal for a new method, Nat. Hazards, 46, 353-389, doi:10.1007/s11069-008-9227-5, 2008.

Koeri: Istanbul Test Area and the Marmara Sea, Tsunami Risk and Loss Assessment, Tsunami Risk ANd Strategies For the European Region (TRANSFER Project), available at: http://www. transferproject.eu (last access: 18 March 2014), 2009.

Koshimura, S., Katada, T., Mofjeld, H. O., and Kawata, Y.: A method for estimating casualties due to the tsunami inundation flow, Nat. Hazards, 39, 265-274, doi:10.1007/s11069-006-00275,2006 .

Leone, F., Lavigne, F., Paris, R., Denain, J. C., and Vinet, F.: A spatial analysis of the December 26th, 2004 tsunami-induced damages: Lessons learned for a better risk assessment integrating buildings vulnerability, Appl. Geogr., 31, 363-375, 2011.

Maruyama, Y., Yamazaki, F., Matsuzaki, S., Miura, H., and Estrada, M.: Development of Building Damage and Tsunami Inundation GIS Dataset following the 2010 Chile Earthquake, Architecture Civil Engineering Environment Journal, available at: http://ares.tu.chiba-u.jp/peru/pdf/output/2010/ 2010ACEE_Maruyama.pdf (last access: 20 May 2015), 2010.

Mazurana, D., Benelli, P., Gupta, H., and Walker, P.: Sex and Age Matter: Improving Humanitarian Response in Emergencies, Feinstein International Center, Tufts University, 2011.

Ministry of Internal Affairs and Communications of Japan, Statistics Bureau: Population Census of Japan 2010, available at: http: //www.ipss.go.jp/p-info/e/psj2012/PSJ2012.asp (last access: 14 May 2015), 2010.
MIT Technology review: available at: http: //www.technologyreview.com/news/423274/

80-seconds-ofwarning-for-tokyo/, last access: 21 May 2015.

Mori, N., Takahashi, T., and The 2011 Tohoku Earthquake Tsunami Joint Survey Group: Nationwide post event survey and analysis of the 2011 Tohoku Earthquake Tsunami, Coastal Eng. J., 54, 1, 1-27, doi:10.1142/S0578563412500015, 2012

Nakahara, S. and Ichikawa, M.: Mortality in the 2011 Tsunami in Japan, J. Epidemiol., 23, 70-73, doi:10.2188/jea.JE20120114, 2013.

National Police Agency of Japan, Emergency Disaster Countermeasures Headquarters: Damage Situation and Police Countermeasures associated with 2011 Tohoku District - off the Pacific Ocean Earthquake, 10 March 2014, available at: http://www.npa. go.jp/archive/keibi/biki/index_e.htm (last access: 14 May 2015), 2014.

OECD (Organization for Economic Co-operation and Development)/EC-JRC (European Commission Joint Research Centre): Handbook on Constructing Composite Indicators, Methodology and Users Guide, OECD Publications, Paris, 2008.

Oxfam: The Tsunami's Impact on Women. Oxfam Briefing Note 30 March 2005, p. 2, available at: www.oxfam.org.uk/what_we do/issues/conflict_disasters/downloads/bn_tsunami_women.pdf (last access: 15 December 2014), 2005.

Pattiaratchi, C. and Wijeratne, E.: Tide Gauge Observations of 2004-2007 Indian Ocean Tsunamis from Sri Lanka and Western Australia, Pure Appl. Geophys., 166, 233-258, doi:10.1007/s00024-008-0434-5, 2009.

Post, J., Wegscheider, S., Mück, M., Zosseder, K., Kiefl, R., Steinmetz, T., and Strunz, G.: Assessment of human immediate response capability related to tsunami threats in Indonesia at a sub-national scale, Nat. Hazards Earth Syst. Sci., 9, 1075-1086, doi:10.5194/nhess-9-1075-2009, 2009.

Reese, S., Cousins, W. J., Power, W. L., Palmer, N. G., Tejakusuma, I. G., and Nugrahadi, S.: Tsunami vulnerability of buildings and people in South Java - field observations after the July 2006 Java tsunami, Nat. Hazards Earth Syst. Sci., 7, 573-589, doi:10.5194/nhess-7-573-2007, 2007.

Reese, S., Bradley, B. A., Bind, J., Smart, G., Power, W., and Sturman, J.: Empirical building fragilities from observed damage in the 2009 South Pacific tsunami, Earth-Sci. Rev., 107, 156-173, 2011.

Rickles-Jordan, A.: "Fillial Responsibility: A Survey Across Time and Oceans", Marquette Elder's Advisor: Vol. 9: Iss. 1, Article 8, available at: http://scholarship.law.marquette.edu/elders/vol9/ iss1/8 (last access: 15 December 2014), 2007.

Robertson, I. N., Carden, L., Riggs, H. R., Yim, S., Young, Y. L., Paczkowski, K., and Witt, D.: Reconnaissance Following the September 29th, 2009 Tsunami in Samoa, University of Hawaii, Research Report UHM/CEE/10-01, 2010.

Rofi, A., Doocy, S., and Robinson, C.: Tsunami mortality and displacement in Aceh province, Indonesia, Disasters, 30, 340-350, doi:10.1111/j.0361-3666.2005.00324.x, 2006.

Ruangrassamee, A., Yanagisawa, H., Foytong, P., Lukkunaprasit, P., Koshimura, S., and Imamura, F.: Investigation of tsunamiinduced damage and fragility of buildings in Thailand after the December 2004 Indian Ocean tsunami, Earthq. Spectra, 22, 377 401, 2006. 
Sahal, A., Leone, F., and Péroche, M.: Complementary methods to plan pedestrian evacuation of the French Riviera's beaches in case of tsunami threat: graph- and multi-agentbased modelling, Nat. Hazards Earth Syst. Sci., 13, 1735-1743, doi:10.5194/nhess-13-1735-2013, 2013.

Saito, F.: Women and the 2011 East Japan Disaster, Gender Develop., 20, 265-279, doi:10.1080/13552074.2012.687225, 2012.

Samoa Bureau of Statistics: Samoa Population and Housing Census Report 2006, available at: http://www.spc.int/prism/nada/index. php/catalog/10 (last access: 1 August 2014), 2008.

Sato, H., Murakami, H., Kozuki, Y., and Yamamoto, N.: Study on a simplified method of tsunami risk assessment, Nat. Hazards, 29, 325-340, doi:10.1023/A:1024732204299, 2003.

Scawthorn, C., Blais, N., Seligson, H., Tate, E., Mifflin, E., Thomas, W., Murphy, J., and Jones, C.: HAZUS-MH flood loss estimation methodology. I: Overview and flood hazard characterization, Nat. Hazards Rev., 7, 60-71, doi:10.1061/(ASCE)15276988(2006)7:2(60), 2006a.

Scawthorn, C., Flores, P., Blais, N., Seligson, H., Tate, E., Chang, S., Mifflin, E., Thomas, W., Murphy, J., Jones, C., and Lawrence, M.: HAZUS-MH flood loss estimation methodology. II: Damage and loss assessment, Nat. Hazards Rev., 7, 72-81, doi:10.1061/(ASCE)1527-6988(2006)7:2(60), 2006b.

Strunz, G., Post, J., Zosseder, K., Wegscheider, S., Mück, M., Riedlinger, T., Mehl, H., Dech, S., Birkmann, J., Gebert, N., Harjono, H., Anwar, H. Z., Sumaryono, Khomarudin, R. M., and Muhari, A.: Tsunami risk assessment in Indonesia, Nat. Hazards Earth Syst. Sci., 11, 67-82, doi:10.5194/nhess-11-67-2011, 2011.

Sugimoto, T., Murakami, H., Kozuki, Y., and Nishikawa, K.: A human damage prediction method for tsunami disasters incorporating evacuation activities, Nat. Hazards, 29, 585-600, 2003.

Suharyanto, A., Pujiraharjo, A., Usman, F., Murakami, K., and Deguchi, C.: Predicting tsunami inundated area and evacuation road based on local condition using GIS, IOSR J. Environ. Sci., Toxicol. Food Technol. (IOSR-JESTFT), 1, 5-11, 2012.

Suppasri, A., Mas, E., Charvet, I., Gunasekera, R., Imai, K., Fukutani, Y., Abe, Y., and Imamura, F.: Building damage characteristics based on surveyed data and fragility curves of the 2011 Great East Japan tsunami, Nat. Hazards, 66, 319-341, doi:10.1007/s11069-012-0487-8, 2013.

Ting, G. and Woo, J.: Elder care: is legislation of family responsibility the solution?, Asian J. Gerontol. Geriatr., 4, 72-75, 2009.

Tinti, S., Tonini, R., Bressan, L., Armigliato, A., Gardi, A., Guillande, R., Valencia, N., and Scheer, S.: Handbook of Tsunami Hazard and Damage Scenarios, SCHEMA project (Scenarios for Hazard induced Emergencies Management), European Commission's Joint Research Centre, Institute for the Protection and Security of the Citizen, EU Publications Office, Luxembourg, ISBN 978-92-79-19062-9, doi:10.2788/21259, 2011.
Tsuji, Y., Namegaya, Y., Matsumoto, H., Iwasaki, S., Kanbua, W., Sriwichai, M., and Meesuk, V.: The 2004 Indian tsunami in Thailand: Surveyed runup heights and tide gauge records, Earth Planet. Space, 58, 223-232, 2006.

UNDP: Risk Assessment and Management for Tsunami Hazard: Case Study of the Port City of Galle Sri Lanka, Published by United Nations Development Programme, Asia-Pacific Regional Centre (Thailand) in partnership with ICG/IOTWSWorking Group on Risk Assessment under the UNESCO/IOC framework, 2011.

UNESCO-IOC: International Tsunami Survey Team Samoa (ITST Samoa): Interim Report of Field Survey 14-21 October 2009, Australian Tsunami Research Centre Miscellaneous Report No. 2, Sydney, 2009.

UNFPA (United Nations Population Fund): Women Studies Centre and Oxfam Great Britain: Gender and changes in tsunamiaffected villages in Nanggroe Aceh Darussalam province, available at: http://policy-practice.oxfam.org.uk/publications (last access: 14 May 2015), 2005.

UN/ISDR (UN International Strategy for Disaster Reduction): Living with Risk: a Global Review of Disaster Reduction Initiatives, 2004 version, UN Publications, Geneva, 2004.

UNU-EHS (United Nations University - Institute for Environment and Human Security): Vulnerability Assessment within Cádiz test area (Western Iberian margin, Spain), Tsunami Risk ANd Strategies For the European Region (TRANSFER Project), available at: http://www.transferproject.eu (last access: 18 March 2014), 2009.

UWI-CDEMA (University of the West Indies Seismic Research Centre and Caribbean Disaster Emergency Management Agency): Tsunami Smart Information Kit for the Caribbean Media, Tsunami and Other Coastal HazardsWarning System Project, Barbados, West Indies, 2010.

Villagrán de León, J. C.: Rapid Assessment of Potential Impacts of a Tsunami. Lessons from the Port of Galle in Sri Lanka, United Nations University Institute for Environment and Human Security (UNU-EHS), SOURCE Publication Series No. 9, Bonn, Germany, ISSN: 1816-1154, 2008.

Vogel, C. and O'Brien, K.: Vulnerability and global environmental change: rhetoric and reality, AVISO No. 13, Global Environmental Change and Human Security Project, Carleton University, Ottawa, 2004.

Wijetunge, L. J.: A deterministic analysis of tsunami hazard and risk for the southwest coast of Sri Lanka, Cont. Shelf Res., 79, 23-35, doi:10.1016/j.csr.2013.09.009, 2014. 